\title{
ANALISIS INDEKS KENYAMANAN IKLIM \\ (Studi Kasus: Taman Wisata Jatim Park 2 dan Karangkates)
}

\author{
RIDWAN FAIZAL ASEP KURNIA
}

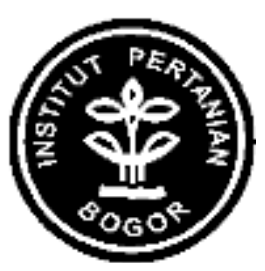

DEPARTEMEN GEOFISIKA DAN METEOROLOGI

FAKULTAS MATEMATIKA DAN ILMU PENGETAHUAN ALAM

INSTITUT PERTANIAN BOGOR

BOGOR

2016 
모 웅

흠마을

을 흐을

可言言

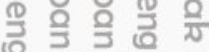

도의

3응을 훙 훙

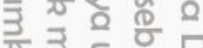

을 옥 올 을.

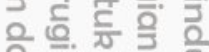

일 정의

了ํㅗㄱ융 을 은

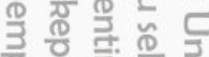

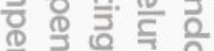

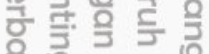

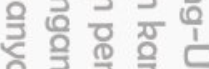

원드을 을

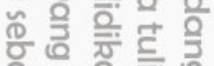

ह

을. 응. 흥

윽 웅

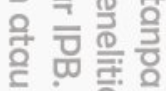

(O)

节

둥

于 豆刍

을 을

일 일

들 을 을

을 글

응 혹 일

每 कृ

익 롱

空 突

응 을

응 응 항

읭

일

흥

촠. 를

ㅁํㅁ

咨

으미

웅

豈

ใ

은

흘

10

킁

을 


\section{PERNYATAAN MENGENAI SKRIPSI DAN SUMBER INFORMASI SERTA PELIMPAHAN HAK CIPTA}

Dengan ini saya menyatakan bahwa skripsi berjudul Analisis Indeks Kenyamanan Iklim (Studi kasus: Taman Wisata Jatim Park 2 dan Karangkates) adalah benar karya saya dengan arahan dari komisi pembimbing dan belum diajukan dalam bentuk apa pun kepada perguruan tinggi mana pun. Sumber informasi yang berasal atau dikutip dari karya yang diterbitkan maupun tidak diterbitkan dari penulis lain telah disebutkan dalam teks dan dicantumkan dalam Daftar Pustaka di bagian akhir skripsi ini.

(C) Dengan ini saya melimpahkan hak cipta dari karya tulis saya kepada Institut Pertanian Bogor.

Bogor, Januari 2016

Ridwan Faizal Asep Kurnia NIM G24110032 
모 웅

흠마을

을 흐을

可言言

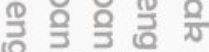

도의

3응을 훙 훙

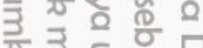

을 옥 올 을.

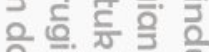

일 정의

了ํㅗㄱ융 을 은

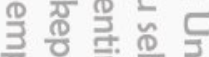

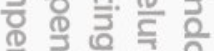

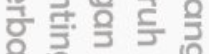

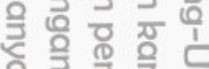

원드을 을

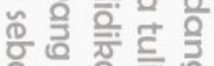

ह

을. 응. 흥

윽 웅

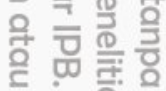

(O)

节

둥

于 豆刍

을 을

일 일

들 을 을

을 글

응 혹 일

每 कृ

익 롱

空 突

응 을

응 응 항

읭

일

흥

촠. 를

ㅁํㅁ

咨

으미

웅

豈

ใ

은

흘

10

킁

을 


\begin{abstract}
ABSTRAK
RIDWAN FAIZAL ASEP KURNIA. Analisis Indeks Kenyamanan Iklim (Studi Kasus: Taman Wisata Jatim Park 2 dan Karangkates). Dibimbing oleh PERDINAN.

Sektor pariwisata menjadi salah satu sektor terbesar dan andalan utama sektor ekonomi di berbagai negara termasuk Indonesia. Kenyamanan iklim merupakan salah satu elemen kunci yang harus dipertimbangkan di daerah tujuan pariwisata seperti kondisi iklim dapat menentukan kegiatan pariwisata. Penelitian ini bertujuan untuk menganalisis tingkat kenyamanan Jatim Park 2 dan Karangkates berdasarkan tiga indeks kenyamanan yaitu: Tourism Climate Index (TCI), Holiday Climate Index (HCI) and Temperature Humidity Index (THI). Analisis ini secara khusus menenkankan untuk mengevaluasi sensitivitas dari setiap metode. Hasil berdasarkan TCI dan HCI menunjukan bahwa Jatim Park 2 lebih nyaman dibandingkan Karangkates. Sementara itu, THI menunjukan bahwa kedua taman wisata dapat digolongkan ke dalam kondisi kenyamanan yang baik. Secara musiman, HCI dan TCI menunjukan bahwa kondisi iklim yang nyaman di wilayah kajian terjadi pada musim kemarau. Hasil test sensitivitas untuk HCI dan TCI menyarankan bahwa HCI dianggap lebih baik diterapkan di daerah tropis yang memiliki curah hujan dan suhu yang relatif tinggi. Sementara itu, TCI sensitif terhadap aplikasi penentuan peringkat curah hujan. Dengan demikian, TCI harus diperhatikan jika diterapkan untuk daerah yang memiliki curah hujan dan suhu yang relatif tinggi, dan peringkat curah hujan perlu disesuaikan.
\end{abstract}

Kata kunci: Holiday Climate Index, Pariwisata, Tourism Climate Index, Temperature Humidity Index 
T RIDWAN FAIZAL ASEP KURNIA. Analyze of Climate Comfortability Index (Case studi: Jatim Park 2 and Karangkates Park). Supervised by PERDINAN

Tourism sector is one of the main economic sectors in many countries including Indonesia. Climate comfortability is one of key element that should be considered at tourist destination as climate condition can determine tourism activity. This research is proposed to analyze the comfortability level of Jatim Park 2 and Karangkates Park based on three comfortability indexes, namely: Tourism Climate Index (TCI), Holiday Climate Index (HCI) and Temperature Humidity Index (THI). The analysis is specifically emphasized to evaluate the sensitivity of each method. The results based on TCI and HCI showed that Jatim Park 2 is more comfort than Karangkates Park. Meanwhile, the THI showed that both parks can be classified into good climate comfortability. Seasonally, the HCI showed that comfortable climate condition in the study area occurs in dry season. The sensitivity test for HCI and TCI suggested that HCI is considered better to be applied in the tropical area which has relatively high rainfall and temperature. While, TCI is sensitive to the application of determined rainfall rating. Thus, the TCI should be carefully applied for a region which has relatively high rainfall and temperature, and the rainfall rating may need to be adjusted accordingly.

Keyword: Holiday Climate Index, Tourism, Tourism Climate Index, Temperature Humidity Index 


\section{ANALISIS INDEKS KENYAMANAN IKLIM \\ (Studi Kasus: Taman Wisata Jatim Park 2 dan Karangkates)}

\section{RIDWAN FAIZAL ASEP KURNIA}

\section{Skripsi}

sebagai salah satu syarat untuk memperoleh gelar

Sarjana Sains

pada

Departemen Geofisika dan Meteorologi

DEPARTEMEN GEOFISIKA DAN METEOROLOGI 
모 웅

흠마을

을 흐을

可言言

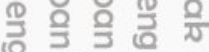

도의

3응을 훙 훙

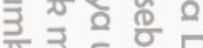

을 옥 올 을.

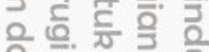

일 정의

了ํㅗㄱ융 을 은

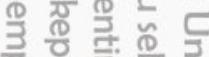

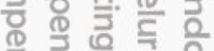

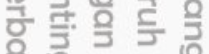

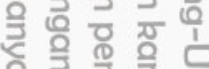

원드을 을

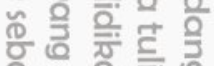

ह

을. 응. 흥

윽 웅

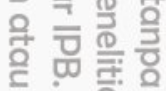

(O)

节

둥

于 豆刍

을 을

일 일

들 을 을

을 글

응 혹 일

每 कृ

익 롱

空 突

응 을

응 응 항

읭

일

흥

촠. 를

ㅁํㅁ

咨

으미

웅

豈

ใ

은

흘

10

킁

을 


\section{(6)}

N Judul Skripsi: Analisis Indeks Kenyamanan Iklim (Studi kasus: Taman Wisata 무 음 Jatim Park 2 dan Karangkates)

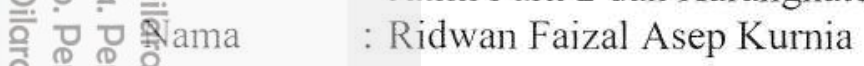

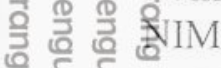

: G24110032

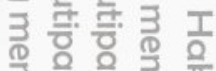

을 空震

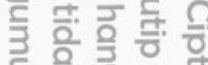

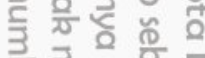

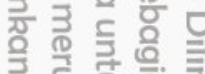

응흘 됙 을

윽 익 융 을

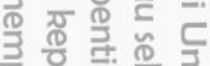

(O)

Disetujui oleh

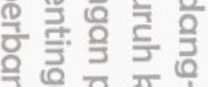

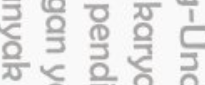

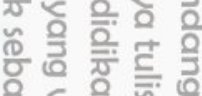

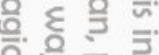

윽윽윯

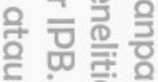

言

을

Tanggal Lulus: 15 JAN 2016

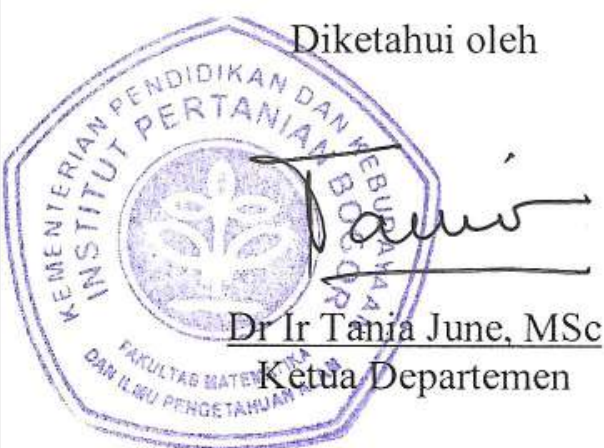


모 웅

흠마을

을 흐을

可言言

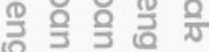

도의

3응을 훙 훙

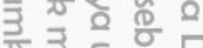

을 옥 올 을.

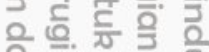

일 정의

了ํㅗㄱ융 을 은

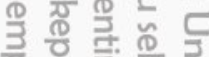

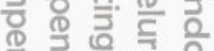

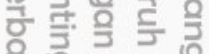

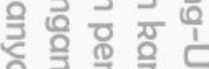

원드을 을

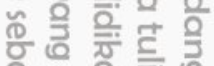

ह

을. 응. 흥

윽 웅

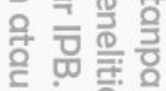

(O)

节

둥

于 豆刍

을 을

일 일

들 을 을

을 글

응 혹 일

每 कृ

익 롱

空 突

응 을

응 응 항

읭

일

흥

촠. 를

ㅁํㅁ

咨

으미

웅

豈

ใ

은

흘

10

킁

을 


\section{PRAKATA}

Puji dan syukur penulis ucapkan kepada Tuhan Yang Maha Esa, karena berkat rahmat dan anugerah-nya penulis dapat menyelesaikan karya tulis yang berjudul Analisis Indeks Kenyamanan Iklim (studi kasus: Taman wisata Jatim Park 2 dan Karangkates).

Penulis ingin mengucapkan terima kasih kepada Ayah dan Ibu tercinta, Asep Kurnia dan Ika Aguseritani yang selalu memberikan dukungan berupa materi dan moral agar karya tulis ini dapat selesai tepat waktu, terima kasih juga untuk adik-adik terhebat Firman Firdaus A.K dan Farhan Farid A.K yang telah memberi penulis semangat dalam menyelesaikan karya tulis ini, serta tidak lupa penulis mengucapkan terima kasih banyak kepada:

1. Dr. Perdinan selaku pembimbing skripsi yang telah memberikan banyak nasihat, arahan dan dukungan moril kepada penulis sehingga dapat terselesaikan dengan baik

3. Dr. Tania June selaku ketua Departemen Geofisika dan Meteorologi dan seluruh dosen maupun staff yang telah memberikan ilmu dan pengetahuan selama penulis berada di IPB ini

3. Seluruh keluarga GFM dan Panser Kuning angkatan 47, 48, 49, 50 dan 51 yang telah menjadi keluarga kedua selama penyelesaian studi di IPB ini dan telah memberikan banyak Ilmu dan pengalaman berharga.

4. Sahabat terbaik selama di IPB Diah dan Lucy yang selalu memberikan support dan bantuannya dalam penyelesaian studi ini.

75. Temen satu bimbingan (Afni Mutia, Miftahudin dan Lina) yang telah banyak membantu dan penyelesaian tugas akhir ini.

6. Keluarga besar Futsal GFM (Adi Kiswanto, Teungku haikal, Firdaus, Ade Nurjaman, Yudistiro Anggeno, Miftahudin, Dionisius), keluarga besar GFM 48, keluarga “Kapan ke semeru” (Doyok, Okta, Ijal, Pacul, Adit, Udin, Heidei, Dion, Rizky dan Yudi), keluarga Pajamas tandingan (Ayuvira, Reffi, Lutha).

Semoga karya ilmiah ini dapat memberikan pengetahuan dan bermanfaat bagi yang memerlukannya.

Bogor, Januari 2016

Ridwan Faizal Asep Kurnia 
모 웅

흠마을

을 흐을

可言言

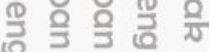

도의

3응을 훙 훙

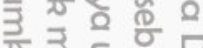

을 옥 올 을.

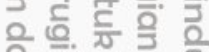

일 정의

了ํㅗㄱ융 을 은

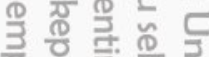

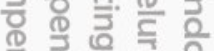

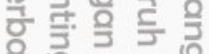

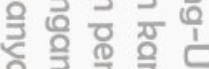

원드을 을

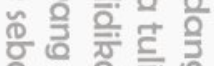

ह

을. 응. 흥

윽 웅

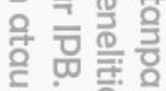

(O)

节

둥

于 豆刍

을 을

일 일

들 을 을

을 글

응 혹 일

每 कृ

익 롱

空 突

응 을

응 응 항

읭

일

흥

촠. 를

ㅁํㅁ

咨

으미

웅

豈

ใ

은

흘

10

킁

을 


\section{DAFTAR ISI}

DAFTAR TABEL $\quad$ xi

DAFTAR GAMBAR Xii

DAFTAR LAMPIRAN xii

PENDAHULUAN 1

Latar Belakang 1

Tujuan Penelitian $\quad 2$

TINJAUAN PUSTAKA 3

Profil Wilayah Kajian 4

Tourism Climate Index $\quad 5$

Temperature Humidity index 6

Holiday Climate index $\quad 7$

METODE PENELITIAN 9

Waktu dan Tempat Penelitian $\quad 9$

$\begin{array}{ll}\text { Alat } & 9\end{array}$

$\begin{array}{lr}\text { Drohan } & 9\end{array}$

三 Prosedur Penelitian $\quad 9$

HASIL DAN PEMBAHASAN 14

$\begin{array}{ll}\text { E. Tourism climate index } & 15\end{array}$

Temperature Humidity Index 20

Holiday Climate Index 21

Perbandingan THI, TCI dan HCI 23

SIMPULAN DAN SARAN 29

$\begin{array}{ll}\text { Kosimpulan } & 29\end{array}$

$\begin{array}{ll}\text { S Saran } & 29\end{array}$

DAFTAR PUSTAKA $\quad 30$

LAMPIRAN $\quad 32$

$\begin{array}{ll}\text { RIWAYAT HIDUP } & 38\end{array}$

\section{DAFTAR TABEL}

1. Aspek Kenyamanan iklim dan pengaruhnya 3

2. Profil Objek Pariwisata Kajian 5

3.J Informasi survei yang dilakukan untuk merancang HCI

4. Perbandingan metode THI, TCI, dan HCI 8

5. Pembobotan komponen Tourism Climate Index 9

6. Skema rating variable (sub indeks) TCI 10

7. Kategori kenyamanan berdasarkan nilai THI 11

8. Pembobotan komponen Holiday Climate Index 12

9. Skema rating variable (sub indeks) HCI 12 
10. Kategori kenyamanan

11. Nilai TCI berdasarkan data observasi Stasiun BMKG Karangploso dan Karangkates tahun 2000-2009

12. Skor THI, TCI dan HCI bulanan objek wisata Taman Wisata Karangkates

13. Skor THI, TCI dan HCI bulanan objek wisata Jatim Park 2

14. Nilai TCI dan HCI pada ilustrasi musim hujan dan kemarau di Taman Wisata Karangkates

15. Nilai TCI dan HCI pada ilustrasi musim hujan dan kemarau di Jatim Park 2

\section{DAFTAR GAMBAR}

1. Grafik kombinasi suhu udara $\left({ }^{\circ} \mathrm{C}\right)$ dan kelembaban udara $(\%)$ untuk menghitung CIA, CID dan suhu efektif.

2. letak wilayah kajian dan stasiun cuaca di Malang, Jawa Timur

3. Nilä TCI Taman Wisata Jatim Park 2 dan Karangkates tahun 2000$200 \overline{9}$

4. Persentase jumlah bulan dengan kondisi iklim baik di Taman Wisata Karangkates Tahun 2000-2009; jumlah bulan $=120$

5. Pers̄entase jumlah bulan dengan kondisi iklim yang nyaman di wisata Jatim Park Tahun 2000-2009; jumlah bulan = 120 bulan.

6. Perbandingan curah hujan dan lama penyinaran Taman Wisata Jatim Park 2 (kiri) dan Karangkates (kanan) 2000-2009.

7. Kontribusi CH terhadap nilai TCI Taman Wisata Jatim Park 2 (kiri) dan Karangkates (kanan) tahun 2000-2009; (Sumber: BMKG Karangploso dan=Karangkates)

8. Kontribusi suhu rata-rata $\left({ }^{\circ} \mathrm{C}\right)$ dan nilai TCI Taman Wisata Jatim Park 2 (kiri) dan Karangkates (kanan) tahun 2000-2009; (Sumber: BMKG Karangploso dan Karangkates)

9. Nilai THI Jatim Park 2 (500-600 mdpl) dan Taman wisata Karangkates (200-300 mdpl) tahun 2000-2009

10. Nilai HCI Jatim Park 2 dan Taman Wisata Karangkates tahun 2000 hingga 2009

11. Kontribusi CH terhadap nilai HCI Taman Wisata Jatim Park 2 (kiri) dan Karangkates (kanan) tahun 2000-2009; (Sumber: BMKG Karangploso dan Karangkates)

12. Kontribusi suhu udara terhadap nilai HCI Taman Wisata Jatim Park 2 (kiri) dan Karangkates (kanan) tahun 2000-2009; (Sumber: BMKG Karangploso dan Karangkates)

\section{DAFTAR LAMPIRAN}

1. Sub indeks TCI Taman Wisata Karangkates

2. Sub indeks TCI Taman Wisata Jatim Park 2 


\section{PENDAHULUAN}

\section{Latar Belakang}

Sektor pariwisata menjadi salah satu sektor terbesar dan andalan utama di dunia dalam menghasilkan devisa di berbagai negara salah satunya adalah Indonesia. Negara yang memiliki sektor pariwisata yang indah dan nyaman memanfaatkannya untuk mendapatkan devisa sebesar mungkin dari para wisatawan. Peranan pariwisata sangat penting terutama dalam hal pembangunan ekonomi dan ketahanan nasional. Penerimaan devisa dari sektor pariwisata terus meningkat seiring dengan meningkatnya total kunjungan wisatawan yang datang ke Indonesia. Berdasarkan data dari BPS pada tahun 2010, sektor pariwisata di Indonesia menyumbang devisa sebesar 7.603,45 juta dolar Amerika Serikat. Sektor pariwisata jikardikelola dengan baik dapat menghasilkan pemasukan daerah dan negara yang menjanjikan sehingga dapat memajukan perekonomian negara dan pembangunan nasional seperti penghasil devisa, meningkatkan kesempatan kerja, dan bahkan dapat meretas kemiskinan. Pitana dan Diarta (2006) menyatakan bahwa sektor pariwisata memberikan 8 dampak positif terhadap kehidupan sosial ekonomi masyarakat lokal antara lain : penerimaan devisa, pendapatan masyarakat, kesempatan peluang kerja, harga, kepemilikan dan kontrol, pembangunan dan pendapatan pemerintah.

Negara yang mengandalkan sektor pariwisata harus memperhatikan beberapa faktor untuk menarik minat para wisatawan yang salah satunya adalah kenyamanan. Kenyamanan di sektor pariwisata utamanya dipengaruhi oleh iklim. Variabilitas dan perubahan iklim di Indonesia mempengaruhi karakteristik dan pola kunjungan, baik nusantara maupun mancanegara (Arifin 2011). Menurut Matzarakis et al. (2004) selain faktor topografi, geografi, landscape, vegetasi dan fauna, faktor cuaca/iklim mempengaruhi daya tarik pariwisata di suatu wilayah. Hamilton dan Lau (2006) menyatakan bahwa informasi iklim menjadi faktor utama dalàm memilih tujuan perjalanan wisata. Kondisi iklim yang nyaman dipadukan dengan daya tarik alam pariwisata yang indah merupakan hal yang sangat penting dan paling mempengaruhi wisatawan untuk mengunjungi daerah tujuan wisata. Hal ini menunjukan bahwa peranan iklim dalam bidang pariwisata cukup besar dan penting yang dapat menentukan daerah tujuan wisata. Suatu daerah wisata memiliki alam yang indah namun iklim dan cuacanya kurang baik maka dapat mengakibatkan wisatawan mengurungkan niat berkunjung sehingga jumlah wisatawan dan pendapatan dari wisatawan menurun di daerah tersebut.

Kondisi iklim dan cuaca menjadi salah satu hal penting untuk kegiatan pariwisata. Kegiatan dan aktivitas pariwisata dapat terganggu jika cuaca dan iklim kurang baik. Seperti contoh jika terjadi hujan dengan intensitas cukup tinggi di tempat wisata, umumnya para pengunjung tidak dapat melakukan aktivitas outdoor dan lebih memilih untuk tinggal di hotel atau rumah. Hal tersebut menunjukan bahwa wisatawan mempertimbangkan kondisi iklim dan cuaca dalam melakukan aktivitas kunjungan ke wilayah pariwisata. Hal tersebut dapat dijadikan landasan bahwa bidang dan aktivitas pariwisata dipengaruhi oleh iklim dan cuaca dalam tingkat tertentu. Hein (2007) mengidentifikasi tentang dampak perubahan iklim terhadap pariwisata di Spanyol di mana hasil model menunjukan bahwa jumlah 


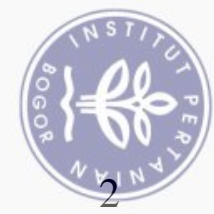

kunjungan ke Spanyol pada tahun 2080 mengalami penurunan sebesar 20\% dibandingkan dengan jumlah pengunjung pada tahun 2004. Contoh lainnya adalah penelitian yang dilakukan oleh Lin dan Matzarakis (2008) yang memanfaatkan $\frac{T}{2}$ informasi curah hujan, lama penyinaran, tekanan udara dan awan untuk mengetahui kenyamanan dan adaptasi terhadap termal. Hubungan iklim dengan pariwisata menjadi menarik untuk diidentifikasi sehingga diperlukan pemahaman lebih mendalam dalam pemanfaatan informasi iklim untuk pengembangan pariwisata.

Pemilihan pariwisata Jatim Park 2 di Kota Batu dan Taman Wisata Karangkates di Kabupaten Malang karena tempat wisata tersebut menjadi tempat pariwisata outdoor yang cukup diminati di Malang dan berdekatan dengan stasiun cuaca Karangploso dan KarangKates. Jatim Park 2 berjarak sekitar 7.93 km dari BMKG Karangploso yang berada di daerah dataran tinggi sedangkan Taman Wisata Karangkates berada sekitar 0.66 km dari Stasiun Cuaca Karangkates yang berada di daerah dataran rendah. Data dari dua stasiun cuaca tersebut dapat dimanfaatkan untuk menganalisis kondisi iklim di wisata Jatim Park 2 dan Taman Wisata Karangkates sehingga dapat diketahui kondisi kenyamanan iklim di dua tempat wisata tersebut berdasarkan Metode Holiday Climate Index (HCI), Tourism Climate index (TCI) dan Temperature Humidity Index (THI). Pemilihan ke tiga metode tersebut karena HCI dan TCI merupakan metode yang dirancang di Eropa khusus untuk daerah pariwisata sedangkan penerapannya di daerah tropis masih sedikit sehingga sensitivitas dan keakuratan metode perlu dikaji di daerah tropis. Sedangkan metode THI merupakan metode yang sudah banyak diterapkan di daerah tropis untuk mengidentifikasi kondisi kenyamanan iklim di luar ruangan. Hasil analisis berdasarkan tiga metode tersebut kemudian dapat bermanfaat sebagai salah satu informasi jadwal kunjungan bagi wisatawan dengan tingkat resiko iklim yang rendah dalam melakukan aktivitas pariwisata di Jatim Park 2 dan Taman Wisata Karangkates.

\section{Tujuan Penelitian}

1. Menganalisis tingkat kenyamanan iklim di Taman Wisata Jatim Park 2 dan Karangkates berdasarkan Metode Tourism Climate Index, Holiday Climate Index dan Temperature Humidity index

2. Menganalisis waktu kunjungan yang disarankan

3. Menganalisis sensitivitas metode dalam penerapannya di Taman Wisata Jatim Park 2 dan Karangkates 


\section{TINJAUAN PUSTAKA}

Iklim merupakan salah satu faktor alam penting yang menjadi perhatian bagi para wisatawan. Menurut Aguiló et al (2005) iklim adalah salah satu penggerak utama dalam pariwisata internasional, sebagaimana sebagian besar wisatawan mencari kesempatan untuk berelaksasi di bawah matahari atau salju. Wisatawan umumnya mencari tempat wisata dengan kondisi iklim yang lebih nyaman dan berbeda dibandingkan dengan kondisi iklim tempat tinggalnya. Mereka yang tinggal di wilayah yang dingin dan jarang mendapat pancaran sinar matahari cenderung berwisata ke wilayah tropis yang lebih hangat. Sebaliknya, mereka yang tinggal di iklim yang cenderung panas, akan mencari daerah tujuan wisata yang sejuk untuk berwisata. Setiap parameter iklim memiliki pengaruh tersendiri terhadap para wisatawan. Berikut ini adalah beberapa aspek iklim pariwisata dan pengaruhnya:

Tabel 1 Aspek Kenyamanan iklim dan pengaruhnya

\begin{tabular}{|c|c|}
\hline Așpek Iklim & Dampak \\
\hline $\begin{array}{l}\text { Termal } \\
\text { Efek suhu udara, kelembaban, } \\
\text { kecepatan angin, radiasi gelombang } \\
\text { pañjang dan pendek serta respons } \\
\text { pribadi terhadap iklim } \\
\text { ( }\end{array}$ & $\begin{array}{l}\text { Dampak fisiologi signifikan } \\
\text { Sensasi panas, kenyamanan termal dan } \\
\text { stres secara psikologi akibat iklim }\end{array}$ \\
\hline Fisik & Dampak Fisik \\
\hline Angin & $\begin{array}{l}\text { Membawa Debu, Pasir dan merusak } \\
\text { properti }\end{array}$ \\
\hline Hựjan & $\begin{array}{l}\text { Basah, mengurangi jarak pandang dan } \\
\text { aktivitas }\end{array}$ \\
\hline Salju & Mengurangi aktivitas outdoor \\
\hline ES & Cedera dan kerusakan properti \\
\hline Kualitas udara & Kesehatan, alergi dan kesejahteraan \\
\hline Radiasi UV & $\begin{array}{l}\text { Kesehatan dan kulit terbakar saat } \\
\text { berjemur }\end{array}$ \\
\hline Estetika & Dampak psikologi \\
\hline Lama penyinaran/ penutupan awan & Daya tarik dan kenikmatan \\
\hline Visibilitas & Daya tarik dan kenikmatan \\
\hline Panjang hari & Periode kegiatan dan kenyamanan \\
\hline
\end{tabular}

Sumber: de Freitas (2003)

Pemanfaatan informasi iklim di sektor pariwisata digunakan oleh tiga pengguna utama yaitu para wisatawan, pengembang pariwisata dan juga lembaga pemerintahan. Pemanfaatan informasi iklim berbeda-beda untuk setiap pengguna. Bagi para wisatawan, prakiraan cuaca di wilayah tujuan wisata dan kondisi cuaca di sepanjang menjadi sangat penting untuk para wisatawan. Kemudian untuk para pengembang pariwisata, informasi iklim yang ada berguna untuk perencanaan strategis pembangunan infrastruktur. Sedangkan untuk lembaga pemerintahan, informasi iklim digunakan untuk mengidentifikasi resiko perubahan iklim dan sebagai acuan untuk program mitigasi ke depannya (Scoot dan Lemieux 2010). 


\section{Profil Wilayah Kajian}

Malang Raya merupakan salah satu daerah pariwisata terbesar di Jawa Timur T yang memiliki banyak tempat wisata yang menarik untuk dikunjungi. Malang Raya " terletak pada koordinat $112^{\circ} 17^{\prime}, 10,90 "$ Bujur Timur dan $122^{\circ} 5^{\prime}, 00,00^{\prime \prime}$ Bujur f Timur dan antara $7^{\circ} 44^{\prime}, 55,11^{\prime \prime}$ Lintang Selatan dan $8^{\circ} 26^{\prime}, 35,45^{\prime \prime}$ Lintang Selatan. Pada umumnya, wisatawan yang berkunjung ke daerah Malang sangat tertarik 믈 dengan kebudayaan dan tempat wisata alami yang terjaga keasriannya. Malang menjadi salah satu daerah yang unik karena memiliki tempat wisata yang komplit seperti wisata bahari laut (pantai), wisata pegunungan (gunung, hutan, air terjun, sumber air), wisata danau, artefak/kebudayaan, candi dan bahkan tempat wisata buatan seperti kolam pemandian dan taman. Jumlah objek wisata di Malang Raya - tersebar cukup merata dan terbanyak berada di Kota Batu. Salah satu objek wisata yang diminati oleh wisatawan adalah Jatim Park 2 dan Taman Wisata Karangkates.

Berikut ini adalah profil dari objek wisata Jatim Park 2 dan Taman Wisata Karangkates:

\section{Jatim Park 2}

Objek Wisata Jatim Park 2 merupakan Kawasan wisata terpadu yang berada di pegunūngan dengan kondisi udara yang sejuk khas pegunungan. Jatim Park 2 letaknya berdekatan dengan Jatim Park 1 yang terletak di lereng Gunung Panderman dengan ketinggian tempat 850 mdpl. Jatim Park 2 memiliki 3 Objek wisata utama di dalamnya, yaitu Batu Secret Zoo, Museum Satwa dan Eco Green Park. Objek wisata Jatim Park 2 dibangun di lahan yang meliputi Desa Oro-Oro Ombo, Kelurahan Temas dan Kecamatan Sihir.

\section{Taman Wisata Karangkates}

Taman Wisata Karangkates terletak di Desa Karang kates Kecamatan Sumber Pucung. Taman Wisata ini merupakan hasil pengembangan dari Pembangunan Bendungan Sutami. Bendungan ini dibangun oleh pemerintah pada tahun 1975 sampai 1977 yang digunakan untuk pembangkit Listrik Tenaga Air. Namun seiring berjalannya waktu, Bendungan ini menjadi salah satu objek wisata yang unik sehingga di bangun menjadi sebuah Taman Wisata. Hal menarik dari Taman Wisata ini terletak pada danau buatan yang di kelilingi oleh pemandangan yang indah dan perbukitan hijau. Pengelolaan terus dilakukan dan telah terdapat beberapa fasilitas kegiatan berwisata.

Berikut ini adalah beberapa informasi mengenai Taman Wisata Jatim Park dan Karangkates: 
Tabel 2 Profil Objek Pariwisata Kajian

\begin{tabular}{|c|c|c|c|}
\hline Objek Wisata & Lokasi & $\begin{array}{l}\text { Jenis Wahana } \\
\text { Wisata }\end{array}$ & $\begin{array}{l}\text { Jumlah } \\
\text { pengunjung }\end{array}$ \\
\hline 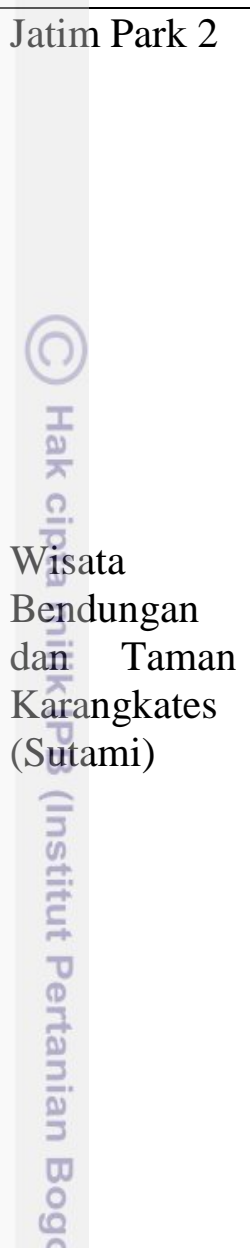 & $\begin{array}{l}\text { Terletak di Desa } \\
\text { Karangkates, } \\
\text { kecamatan Sumber } \\
\text { Pucung Kabupaten } \\
\text { Malang (sekitar } 40 \mathrm{~km} \\
\text { ke arah Barat daya } \\
\text { Kota Malang) }\end{array}$ & $\begin{aligned} & 36 \text { wahana dengan } \\
& 3 \text { wahana Utama } \\
& \text { yaitu : } \\
& \text { 1. Museum } \\
& \text { Satwa } \\
& \text { 2. Secret Doo } \\
& \text { 3. Pohon Inn } \\
& \text { Hotel } \\
& \text { 4. Dan Wisata } \\
& \text { Outdoor } \\
& \text { lainnya } \\
& \text { 1. Fasilitas } \\
& \text { memancing } \\
& \text { 2. Sarana } \\
& \text { Olahraga } \\
& \text { 3. Kebun } \\
& \text { Binatang } \\
& \text { Mini } \\
& \text { 4. Camping } \\
& \text { Ground } \\
& \text { 5. Perahu } \\
& \text { wisata } \\
& \text { 6. Arena } \\
& \text { Outbond } \\
& \text { 7. Banana } \\
& \text { Boat }\end{aligned}$ & $\begin{array}{l}\text { Pada Hari biasa } \\
\text { sekitar 300-400 } \\
\text { orang/hari. } \\
\text { Sedangkan hari } \\
\text { libur bisa } \\
\text { meningkat hingga } \\
\text { 5x lipat. }\end{array}$ \\
\hline
\end{tabular}

\section{Tourism Climate Index}

Tourism climate index (TCI) merupakan sebuah konsep dalam penentuan kenyamanan dalam bidang pariwisata untuk para turis. TCI dirancang berdasarkan literatur yang berkaitan dengan klasifikasi iklim untuk turis dan rekreasi dengan pertimbangan teoritis dari literatur Biometeorologi terkait dengan kenyamanan manusia (Scoot et al. 2004). Konsep ini dirancang oleh Mieczkowski pada tahun 1985 yang menghubungkan faktor-faktor iklim seperti curah hujan, kecepatan angin, suhu udara dan jumlah radiasi matahari dengan tingkat kenyamanan daerah pariwisata. Metode dan konsep yang dikemukakan oleh Mieczkowski bertujuan untuk menilai implikasi dari perubahan iklim di masa depan terhadap tingkat kenyamanan relatif pengunjung di suatu wilayah khususnya daerah pariwisata.

2 Variabel iklim yang digunakan dalam TCI yaitu suhu maksimum, suhu ratarata, kelembaban relatif minimum, kelembaban relatif, curah hujan, lama penyinaran dan kecepatan angin. Kombinasi variabel iklim menghasilkan nilai TCI di wilayah kajian pada selang 0-100. Pada selang nilai TCI, TCI dikategorikan ke 


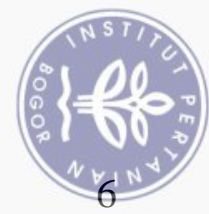

dalam 4 kategori utama yaitu kategori ideal, baik, dapat ditoleransi dan buruk (Mieczkowski 1985).

Penggunaan Tourism Climate Index (TCI) untuk menilai kondisi saat ini dan T potensi pariwisata akan memberikan dua jenis informasi yaitu, wilayah dengan kondisi kenyamanan yang baik dan waktu kunjungan yang disarankan. TCI dapat dijadikan sebagai alat untuk mengetahui kualitas iklim di suatu wilayah yang cenderung dinamis yang dapat mempengaruhi keputusan para wisatawan. Pemeriksaan potensi dampak perubahan iklim di Skotlandia menyimpulkan bahwa perubahan iklim yang saat ini sedang terjadi telah berdampak pada pola pola aktivitas pengunjung dan mengancam sistem keuangan perusahaan yang bergerak di bidang pariwisata dan sistem keuangan turis (Harisson et al. 1999).

\section{Temperature Humidity index}

Indeks kenyamanan manusia ditentukan oleh sensasi panas yang diterima oleh manüsia dalam melakukan aktivitas. Temperature Humidity index merupakan indeks kenyamanan yang menggabungkan faktor suhu udara dan suhu bola basah yang kemudian Nieuwolt memodifikasi THI dengan mengombinasikan suhu udara dan kelembaban relatif dalam bentuk persamaan (Kakon et al. 2010). THI menjadi salah satu indikator kenyamanan manusia yang menitik beratkan pada suhu dan kelembaban relatif dan metode ini telah banyak digunakan di wilayah tropis khususnyā di luar ruangan.

Suhu udara memiliki kaitan dengan kenyamanan. Suhu menjadi parameter iklim yang sangat berpengaruh terhadap kenyamanan yang dirasakan oleh manusia. Semakin meningkat suhu udara hingga melebihi batas tertentu, kenyaman yang dirasakan oleh manusia akan semakin berkurang karena sensasi panas dari suhu udara akān terlalu besar dirasakan manusia. Sebaliknya semakin menurun suhu hingga batas tertentu, maka kenyamanan yang dirasakan manusia juga akan semakin menurun karena terlalu dingin (Hidayat 2010).

Kenyamanan pada dasarnya tidak hanya dipengaruhi suhu udara saja tetapi juga di pengaruhi parameter iklim lain dan subjek yang merasakan kenyamanan. Parameter iklim yang juga berpengaruh terhadap kenyamanan manusia adalah angin. Angin dapat membawa udara panas ke tempat lain mencampurkan antara udara panas dan udara dingin serta udara lembab dan udara kering (Lakitan 2002). Manusia yang melakukan aktivitas lebih banyak akan cenderung sensitif terhadap perubahan suhu. Pemanfaatan informasi kenyamanan di suatu wilayah tujuan pariwisata dapat dijadikan referensi untuk menghindari dampak buruk dari iklim. Contohnya adalah pada saat akan berwisata ke daerah pegunungan yang bersuhu rendah, wisatawan dapat mencegah kedinginan dengan membawa baju hangat seperti jaket dan syal. 


\section{Holiday Climate index}

Holiday Climate Index merupakan indeks iklim pariwisata terbaru yang dirancang untuk mengatasi kekurangan dan keterbatasan dari indeks iklim pariwisata TCI. Indeks iklim HCI dirancang khusus untuk kegiatan rekreasi outdoor wisatawan yang hampir sama dengan indeks iklim TCI. HCI dapat dijadikan referensi dalam melakukan kunjungan ke daerah pariwisata yang diinginkan. Kelebihan HCI dibandingkan dengan TCI terletak pada skala peringkat tiap komponen iklim dan bobot dari setiap parameter berdasarkan literatur iklim dan pariwisata yang tersedia yang diperoleh dari hasil survei selama 10 tahun terakhir. Berikut ini adalah beberapa survei yang telah dilakukan oleh beberapa ilmuwan dalam merancang Holiday Climate Index :

Tabēl 3 Informasi survei yang dilakukan untuk merancang HCI

\begin{tabular}{|c|c|c|c|c|}
\hline Peñulis & $\begin{array}{l}\text { Wilayah } \\
\text { kajian }\end{array}$ & $\begin{array}{l}\text { Jumlah } \\
\text { sample }\end{array}$ & $\begin{array}{l}\text { Kelompok } \\
\text { sasaran }\end{array}$ & segmen pasar \\
\hline 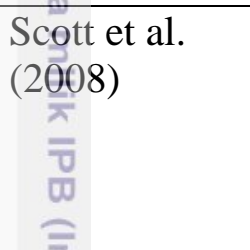 & $\begin{array}{l}\text { Kanada, } \\
\text { Selandia Baru } \\
\text { dan Swedia }\end{array}$ & $\begin{array}{l}863 \text { (333 dari } \\
\text { Kanada, } 207 \\
\text { dari Selandia } \\
\text { Baru dan } 291 \\
\text { dari Swedia }\end{array}$ & Mahasiswa & $\begin{array}{l}\text { Muda- } \\
\text { Dewasa }\end{array}$ \\
\hline $\begin{array}{l}\text { Moreno } \\
(2010) \\
\overline{7}\end{array}$ & $\begin{array}{l}\text { Belgia dan } \\
\text { Bandara di } \\
\text { Belanda }\end{array}$ & 115 & Wisatawan & Dewasa \\
\hline $\begin{array}{l}\text { Rutty \& Scott } \\
(2010) \\
\frac{0}{5} \\
\infty \\
\circ \\
\frac{6}{\circ}\end{array}$ & $\begin{array}{l}\text { Negara- } \\
\text { negara Eropa } \\
\text { Utara }\end{array}$ & $\begin{array}{l}850 \text { ( } 230 \text { dari } \\
\text { Austria, } 303 \\
\text { dari Jerman, } \\
163 \text { dari } \\
\text { Belanda, } 81 \\
\text { dari Swedia } \\
\text { dan } 89 \text { dari } \\
\text { Swiss }\end{array}$ & Mahasiswa & $\begin{array}{l}\text { Muda - } \\
\text { Dewasa }\end{array}$ \\
\hline
\end{tabular}

Sumber: Mantao, T (2013)

HCI menjadi indeks yang dianggap paling baik karena menggunakan data harian dan menjadi keunggulan dibanding indeks iklim lainnya. Penggunaan data harian untuk mengatasi kelemahan dari TCI yang memiliki skala temporal yang rendah. Penggunaan data Harian dalam HCI menjadikan skala resolusinya semakin baik untuk setiap variabel, terutama curah hujan. Data curah hujan harian memberikan informasi Intensitas dan kejadian hujan bukan hanya jumlah hujan dalam satu bulan. Hal tersebut sangat penting untuk diketahui wisatawan karena pada dasarnya kegiatan pariwisata oleh para wisatawan berjangka waktu pendek dalam hitungan hari/Minggu.

Berikut ini adalah perbandingan antara Metode THI, HCI dan TCI: 
Tabel 4 Perbandingan metode THI, TCI, dan HCI

\begin{tabular}{|c|c|c|c|c|}
\hline $\begin{array}{l}\text { Indeks } \\
\text { kenyamanan }\end{array}$ & Variabel & $\begin{array}{l}\text { Data yang } \\
\text { digunakan }\end{array}$ & Kelebihan & kelemahan \\
\hline $\begin{array}{l}\text { Temperature } \\
\text { Humidity } \\
\text { Index (THI) }\end{array}$ & $\begin{array}{l}\text { - Suhu rata-rata } \\
\left({ }^{\circ} \mathrm{C}\right) \\
\text { - } \text { Kelembaban } \\
\text { relatif }(\%)\end{array}$ & $\begin{array}{l}\text { Harian/ } \\
\text { bulanan }\end{array}$ & $\begin{array}{l}\text { - } \text { Metode } \\
\text { perhitungannya mudah } \\
\text { - Data yang diperlukan } \\
\text { tersedia di seluruh } \\
\text { Stasiun cuaca } \\
\text { - Baik digunakan untuk } \\
\text { mengukur } \\
\text { kenyamanan ruangan } \\
\text { (indoor) }\end{array}$ & $\begin{array}{l}\text { - Hanya } \\
\text { menggunakan } \\
\text { aspek termal }\end{array}$ \\
\hline 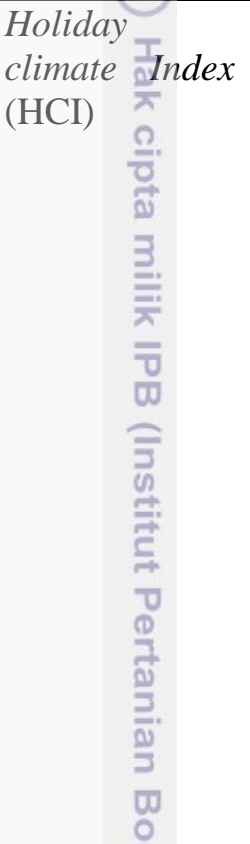 & $\begin{array}{l}\text { - Suhu efektif } \\
\text { (Suhu max + } \\
\text { kelembaban } \\
\text { rata-rata) } \\
\text { - Penutupan } \\
\text { awan (\%) } \\
\text { - Curah hujan } \\
\text { (mm) } \\
\text { - Kecepatan } \\
\text { angin (km/jam) }\end{array}$ & Harian & $\begin{array}{l}\text { - Sistem } \\
\text { pembobotannya } \\
\text { berdasarkan literatur } \\
\text { hasil survei dari } \\
\text { wisatawan } \\
\text { - Penggunaan data } \\
\text { harian memberikan } \\
\text { informasi lebih detail } \\
\text { dan cocok untuk } \\
\text { kegiatan pariwisata } \\
\text { yang berdurasi } \\
\text { pendek. } \\
\text { - Parameter iklim yang } \\
\text { digunakan } \\
\text { menggunakan } 3 \text { unsur } \\
\text { penting dalam } \\
\text { pariwisata } \\
\text { (kenyamanan termal, } \\
\text { Aesthetic, dan fisik) }\end{array}$ & $\begin{array}{l}\text { - Metode ini } \\
\text { masih relatif } \\
\text { sedikit } \\
\text { penerapannya }\end{array}$ \\
\hline $\begin{array}{l}\text { Tourism } \\
\text { Climate Index } \\
\text { (TCI) }\end{array}$ & $\begin{array}{l}\text { - Suhu rata-rata } \\
\left({ }^{\circ} \mathrm{C}\right) \\
\text { - Suhu } \\
\text { maksimum } \\
\left({ }^{\circ} \mathrm{C}\right) \\
\text { - Kelembaban } \\
\text { rata-rata }(\%) \\
\text { - Kelembaban } \\
\text { minimum }(\%) \\
\text { - Lama } \\
\text { penyinaran } \\
\text { - Curah hujan } \\
\text { (mm) } \\
\text { - Kecepatan } \\
\text { angin }(\mathrm{km} / \mathrm{jam}) \\
\end{array}$ & bulanan & $\begin{array}{l}\text { - Menggunakan banyak } \\
\text { parameter iklim } \\
\text { sehingga hasilnya } \\
\text { akan lebih akurat dan } \\
\text { baik } \\
\text { - Telah aplikasikan di } \\
\text { banyak negara } \\
\text { - Menggunakan tiga } \\
\text { aspek penting } \\
\text { pariwisata (Termal, } \\
\text { estetika dan fisik) }\end{array}$ & $\begin{array}{l}\text { - Subjektivitas } \\
\text { dalam sistim } \\
\text { pembobotan } \\
\text { dan rating } \\
\text { variabel iklim } \\
\text { yang } \\
\text { digunakan } \\
\text { - Resolusi } \\
\text { rendah karena } \\
\text { menggunakan } \\
\text { data bulanan } \\
\text { - Pembobotan } \\
\text { berlebih pada } \\
\text { aspek termal }\end{array}$ \\
\hline
\end{tabular}




\section{METODE PENELITIAN}

\section{Waktu dan Tempat Penelitian}

Penelitian dilaksanakan di Laboratorium Klimatologi Departemen Geofisika dan Meteorologi FMIPA Institut Pertanian Bogor. Waktu penelitian dilaksanakan pada bulan April hingga bulan Desember tahun 2015.

\section{Alat}

Peralatan yang digunakan dalam penelitian ini adalah seperangkat komputer dengan perangkat lunak Arcgis 10.1 untuk pemetaan dan penandaan wilayah kajian, Ms. Word dan Ms. Excel untuk pengolahan data. Grafik Daytime Comfort index (CID) dan Daily Comfort Index (CIA) untuk menentukan nilai CID dan CIA dalam perşamaan TCI.

\section{ने Bahan}

Bahan yang digunakan dan diperlukan dalam penelitian ini adalah data obsērvasi harian BMKG tahun 2000-2009 yang meliputi parameter suhu maksimum, suhu minimum, suhu maksimum, kelembaban udara, lama penyinaran dan curah hujan. Data kecepatan angin dan penutupan awan menggunakan data ERA-Interim yang diakses melalui ECMWF (Europe Center for Medium Range Weather Forecasting). Data ERA-Interim merupakan data spasial dengan cakupan $\left(0.125 \times 0.125^{\circ}\right)$ dan resolusi waktu yang tinggi yang sangat bermanfaat untuk kajian meteorologi. Data ERA-Interim merupakan data parameter iklim berupa data model dan data reanalysis yang telah divalidasi menggunakan observasi lapang. Selaîn itu data yang digunakan adalah data ketinggian dengan menggunakan data SRTM.

\section{Prosedur Penelitian}

\section{Tourism Climate Index (TCI)}

Metode yang digunakan dalam penelitian ini menggunakan pendekatan TCI (Tourism Climate Index). Mieczkowski (1985) berpendapat bahwa tujuan pariwisata dipengaruhi kondisi iklim yang nyaman bagi para pengunjung. Nyaman dalam hal ini berarti bahwa kondisi iklim di wilayah tersebut tidak terlalu panas dan tidak terlalu dingin. Metode TCI dirancang oleh Mieczkowski (1985) dengan persamaan berikut ini:

$$
T C I=(8 \times C I D)+(2 \times C I A)+(4 \times R)+(4 \times S)+(2 \times W)
$$

Tabel 5 Pembobotan komponen Tourism Climate Index

\begin{tabular}{ccccc}
\hline 0 & Aspek & Sub indeks & Variabel iklim & $\begin{array}{c}\text { Bobot } \\
\text { parameter }\end{array}$ \\
\hline \multirow{2}{0}{} & \multirow{2}{*}{ Termal } & CID $(*)$ & Suhu max $\left({ }^{\circ} \mathrm{C}\right)+\mathrm{RH}$ min & $40 \%$ \\
& CIA $(*)$ & Suhu $\left({ }^{\circ} \mathrm{C}\right)+\mathrm{RH}$ rataan & $10 \%$ \\
\hline & Estetis & $\mathrm{S}$ & Lama Penyinaran $(\%)$ & $20 \%$ \\
\hline \multirow{2}{*}{ Fisik } & $\mathrm{R}$ & Curah Hujan harian $(\mathrm{mm})$ & $20 \%$ \\
& $\mathrm{~W}$ & Kecepatan Angin $(\mathrm{km} / \mathrm{jam})$ & $10 \%$ \\
\hline
\end{tabular}




\begin{tabular}{|c|c|c|c|c|}
\hline \multicolumn{5}{|c|}{$\begin{array}{l}\text { CID merupakan indeks kenyamanan pada siang hari. Nilai CID didapat dari } \\
\text { kombinasi suhu harian maksimum dengan kelembaban relatif minimum untuk } \\
\text { lai tingkat kondisi iklim pada siang hari. Sedangkan CIA merupakan indeks } \\
\text { amanan harian yang nilainya didapatkan dari hasil kombinasi suhu harian dan } \\
\text { nbaban relatif harian yang diukur selama } 24 \text { jam. Titik pertemuan Kombinasi } \\
\text { dan kelembaban relatif menghasilkan rating/indeks yang digunakan dalam } \\
\text { maan TCI. Ranting yang diberikan untuk semua parameter yang digunakan } \\
\text { n metode TCI ini berkisar dari -3 hingga 5. Peringkat yang mendekati nilai } 5 \\
\text { andakan bahwa parameter tersebut ideal untuk membentuk lingkungan yang } \\
\text { an. Berikut ini adalah tabel skema peringkat TCI untuk masing-masing } \\
\text { neteryang telah dirancang oleh Mieczkowski (1985): } \\
\text { l S Skema rating variable (sub indeks) TCI }\end{array}$} \\
\hline rating & $\begin{array}{c}\left({ }^{\circ} \mathrm{C}\right) \\
\end{array}$ & $\begin{array}{c}\text { Curah hujan } \\
\text { bulanan } \\
(\mathrm{mm})\end{array}$ & $\begin{array}{c}\text { Lama } \\
\text { penyinaran } \\
\text { (jam) }\end{array}$ & $\begin{array}{l}\text { Kecepatan angin } \\
(\mathrm{km} / \mathrm{jam})\end{array}$ \\
\hline 5.0 & $20-26$ & $0-14,9$ & $>10$ & $<2,88$ \\
\hline 4.5 & $\begin{array}{l}19 \\
27\end{array}$ & $15-29.9$ & 9 & $2,88-5,75$ \\
\hline 4.0 & के & $30-44.9$ & 8 & $5,76-9,03$ \\
\hline 3.5 & $\begin{array}{l}17 \\
29\end{array}$ & $45-59.9$ & 7 & $9,04-12,23$ \\
\hline 3.0 & $\begin{array}{l}16 \\
30\end{array}$ & $60-74.9$ & 6 & $12,24-19,79$ \\
\hline 2.5 & $\begin{array}{c}10-15 \\
31\end{array}$ & $75-89.9$ & 5 & $19,8-24,29$ \\
\hline 2.0 & $\begin{array}{c}5-9 \\
32\end{array}$ & $90-104.9$ & 4 & $24,30-28,79$ \\
\hline 1.5 & $\begin{array}{l}0-4 \\
33\end{array}$ & $105.0-119.9$ & 3 & $28,8-38,52$ \\
\hline 1.0 & $\begin{array}{c}(-5)-(-1) \\
34\end{array}$ & $120-134.9$ & 2 & - \\
\hline 0.5 & 35 & $135-149.9$ & 1 & - \\
\hline 0.25 & - & - & - & - \\
\hline 0 & $\begin{array}{c}(-10)-(-6) \\
>36\end{array}$ & $>150$ & $<1$ & $>38,52$ \\
\hline-1.0 & $(-15)-(-11)$ & - & - & - \\
\hline-2.0 & $(-20)-(-16)$ & - & - & - \\
\hline-3.0 & $<(-20)$ & - & - & - \\
\hline
\end{tabular}

Sumber: Mieczkowski (1985).

Tabel 6 dapat digunakan sebagai acuan dalam perhitungan TCI. Formula dan persamaan TCI yang telah dirancang oleh Mieczkowski, memiliki bobot yang berbeda untuk masing-masing parameter. Indeks kenyamanan siang hari (CID) memiliki bobot tertinggi sekitar $40 \%$ yang mencerminkan bahwa tingkat aktivitas tertinggi para wisatawan terjadi pada siang hari sehingga kondisi iklim dalam membentuk lingkungan yang nyaman pada siang hari sangat berpengaruh. Variabel 
sinar matahari dan curah hujan diberi bobot sekitar 20 persen, sedangkan indeks Kenyamanan Harian (CIA) 10 persen dan kecepatan angin 10 persen.

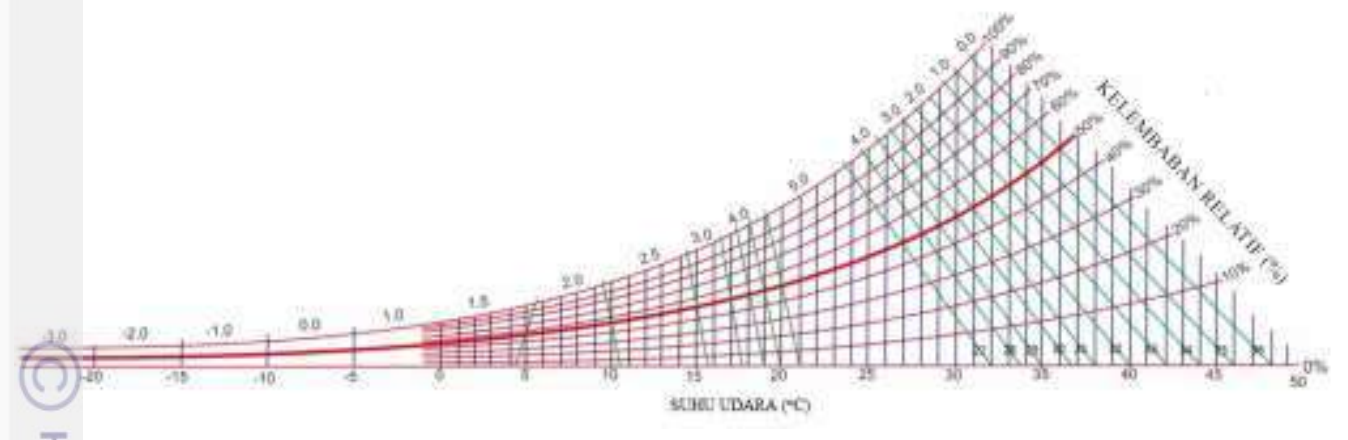

Gambar 1 Grafik kombinasi suhu udara $\left({ }^{\circ} \mathrm{C}\right)$ dan kelembaban udara $(\%)$ untuk menghitung CIA, CID dan suhu efektif.

Nilai TCI tersebut kemudian dihitung dengan menggunakan Ms.excel. Arcgis digünakan untuk memetakan Malang Raya berdasarkan ketinggian. Kemudian dilakukan penandaan pada lokasi Objek wisata kajian dan letak BMKG terdekat.

\section{2. $\overline{7}$ Temperature Humidity index (THI)}

Temperature Humidity Index merupakan metode untuk menganalisis kenyamanan iklim suatu wilayah yang banyak digunakan di daerah tropis. Tingkat kenyamanan ditentukan oleh dua parameter iklim utama yaitu suhu udara dan kelembaban relatif. Hasil perhitungan di tuliskan dalam bentuk angka dan kategori yang menghasilkan indeks yang menetapkan pengaruh sensasi panas terhadap kenyamanan yang dirasakan manusia yang bersifat objektif.

2 Penentuan indeks kenyamanan berdasarkan metode THI menghubungkan antara kondisi suhu dan kelembaban relatif di wilayah kajian yang dikembangkan (Niêwolt 1977) dalam bentuk persamaan sebagai berikut:

$$
T H I=(0.8 \times T)+\left\{\frac{R H \times T}{500}\right\}
$$

Temperature Humidity Index adalah nilai Indeks kenyamanan, T adalah suhu udara dalam satuan $\left({ }^{\circ} \mathrm{C}\right)$ dan $\mathrm{RH}$ adalah kelembaban relatif dalam satuan (\%). Kemudian nilai indeks kenyamanan digunakan untuk menentukan kategori kenyamanan di wilayah kajian. Emmanuel (2005) mengategorikan kenyamanan berdasarkan penilaian responden yang kemudian didapat kategori berdasarkan rentang nilai THI, yaitu:

Tabel 7 Kategori kenyamanan berdasarkan nilai THI

\begin{tabular}{cccc}
\hline & Nilai THI & Sensasi suhu & Nilai THI \\
\hline 0 & $<8$ & Tidak nyaman (terlalu dingin) & $<20$ \\
0 & $8 \leq \mathrm{THI} \leq 21$ & Ditoleransi $($ nyaman jika ada cahaya) & \\
\hline 0 & $21 \leq \mathrm{THI} \leq 24$ & Nyaman & $20-26$ \\
\hline 0 & $24<\mathrm{THI} \leq 26$ & Ditoleransi (nyaman jika ada angin) & \\
$\mathrm{T}$ & THI $>26$ & Tidak Nyaman & $>26$ \\
\hline
\end{tabular}

Sumber: Talaila et al (2013) dan Effendy et al (2005) 


\section{Holiday Climate Index (HCI)}

Holiday Climate Index (HCI) merupakan indeks Iklim yang dikembangkan untuk pariwisata dan merupakan generasi terbaru dari indeks sebelumnya yaitu T TCI. Pembobotan HCI dirancang berdasarkan hasil survei yang dilakukan dan

bobot terbesar tidak menekankan pada suhu. Berikut ini adalah persen bobot parameter $\mathrm{HCI}$ :

Tabel 8 Pembobotan komponen Holiday Climate Index

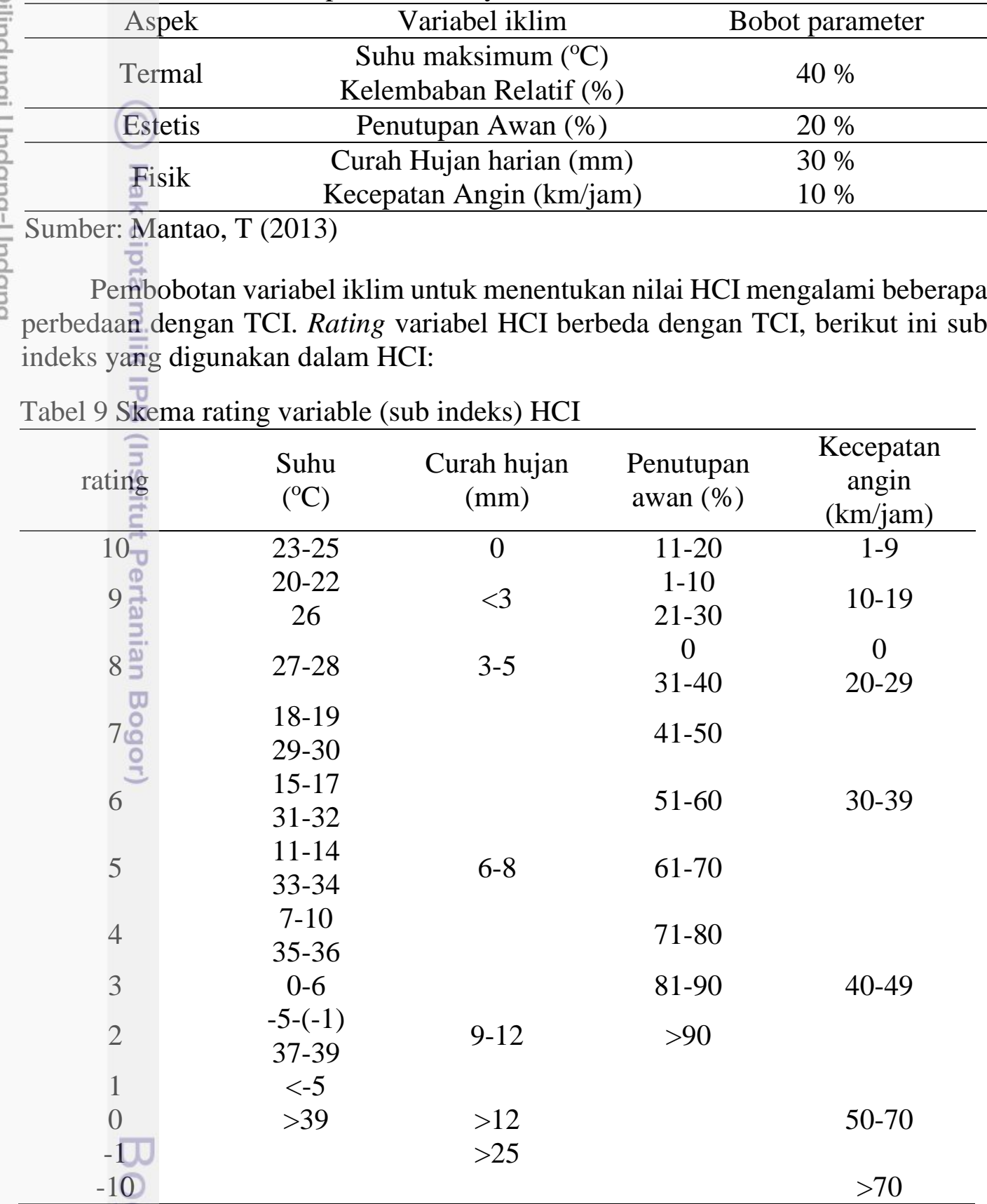

Sumber: Mantao, T (2013) 
Nilai HCI kemudian dihitung berdasarkan pembobotan variabel iklim yang digunakan dengan persamaan berikut:

$$
H C I=(\mathrm{T} \times 4)+(\mathrm{A} \times 2)+[(R \times 3)+(W \times 1)]
$$

Hasil perhitungan dan Nilai HCI yang didapat kemudian di kategorikan dalam 10 kategori yang di rancang oleh Mieczkowski (1985). Berikut ini adalah kategori kenyamanan berdasarkan nilai HCI dan TCI:

Tabel 10 Kategori kenyamanan

\begin{tabular}{|c|c|c|c|}
\hline 6 & Indeks TCI & Kategori & Keterangan \\
\hline 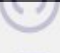 & $90-100$ & Ideal & \multirow{4}{*}{ Nyaman } \\
\hline I & $80-89$ & Sangat bagus & \\
\hline $\bar{\pi}$ & $70-79$ & Baik & \\
\hline$\frac{2}{2}$ & $60-69$ & Cukup Baik & \\
\hline (3) & $50-59$ & Ditoleransi & \multirow{7}{*}{ Tidak Nyaman } \\
\hline 콜 & $40-49$ & $\begin{array}{l}\text { Batas kondisi di } \\
\text { toleransi (umum) }\end{array}$ & \\
\hline$\overline{\mathrm{v}}$ & $30-39$ & Tidak baik & \\
\hline w & $20-29$ & Sangat tidak baik & \\
\hline$\overline{7}$ & $10-19$ & Sangat ekstrim & \\
\hline$\Rightarrow$ & $9-(-9)$ & Tidak memungkinkan & \\
\hline$\stackrel{5}{\Rightarrow}$ & $-30-9$ & Tidak memungkinkan & \\
\hline
\end{tabular}

Sumber: Mieczkowski (1985) 


\section{HASIL DAN PEMBAHASAN}

I Pariwisata merupakan kegiatan memanfaatkan kekayaan alam dan lingkungan hidup yang khas seperti peninggalan sejarah, pemandangan alam yang f indah dan iklim yang aman (Rahardjo 2001). Bidang pariwisata menjadi salah satu k kontributor utama dalam bidang ekonomi sebagai penghasil devisa bagi pembangunan ekonomi negara. Indonesia memiliki keunggulan iklim dibidang pariwisata karena letaknya berada di wilayah ekuator dengan kondisi iklim yang relatif nyaman bagi para wisatawan. Selain itu, keindahan alam yang ditawarkan beraneka ragam seperti gunung, pantai, situs purba kala dan lainnya yang tersebar di seluruh daerah di Indonesia menjadikan daya tarik bagi wisatawan untuk berkunjung.

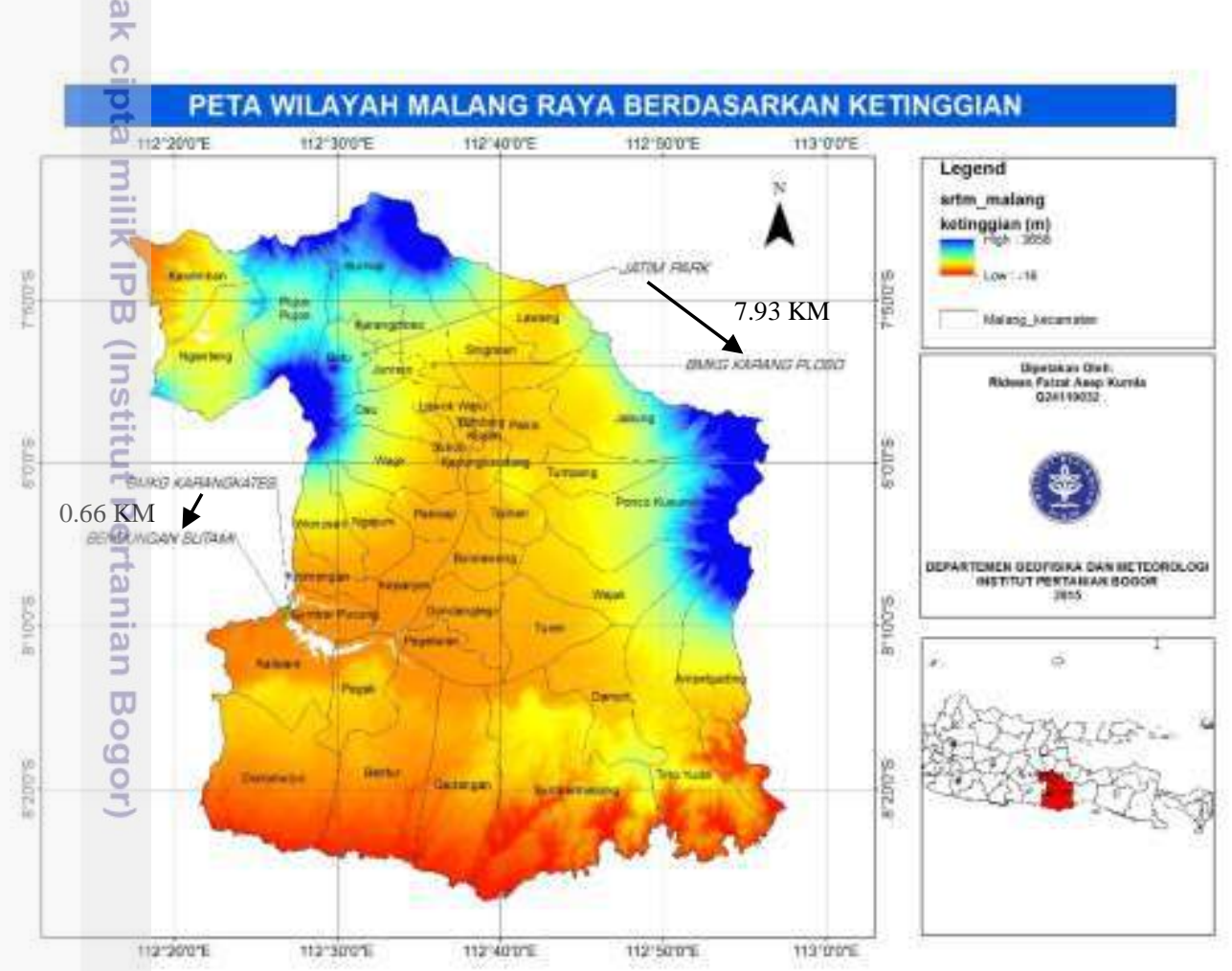

Gambar 2 letak wilayah kajian dan stasiun cuaca di Malang, Jawa Timur

Objek Wisata di Malang Raya jumlahnya cukup banyak dan tersebar di seluruh bagian Malang Raya. Dua objek wisata favorit diantaranya Jatim Park 2 dan Taman Wisata Karangkates. Jatim Park 2 yang berada di Kota Batu tepatnya di kaki Gunung Pandeman yang memiliki udara khas pegunungan yang sejuk menjadi salah satu objek wisata yang diminati oleh para wisatawan lokal maupun dari luar. Tahun 2012 tercatat 804.679 Wisatawan berkunjung ke Jatim Park 2 (BPS Kota Batu, 2013). Wahana hiburan yang lengkap dan memiliki sarana edukasi menjadi salah satu alasan objek wisata ini diminati para wisatawan. Wahana hiburan Taman wisata Karangkets tidak jauh berbeda dengan Jatim Park 2. Taman Wisata Karangkates memiliki wahana yang menarik seperti sarana outbound, memancing, dan kebun binatang mini dengan total pengunjung sekitar 144.000 orang per tahun. 
Wahana hiburan di kedua objek wisata sebagian besar wahana untuk kegiatan dan aktivitas Outdoor.

\section{Tourism Climate Index}

Tourism Climate Index (TCI) merupakan sebuah index yang berupaya menilai kecocokan iklim untuk tujuan pariwisata yang dikembangkan menggunakan parameter iklim seperti suhu, curah hujan, kelembaban relatif, lama penyinaran dan kecepatan angin. Pemilihan parameter ini berdasarkan literatur terkait tentang klasifikasi iklim untuk pariwisata dan literatur Biometeorologi terkait dengan kenyamanan manusia (Scott et al. 2004). Informasi yang diperoleh dari TCI yaitu kondisi iklim di setiap bulan berdasarkan kategori TCI (Tabel 5) dan informasi mengenai waktu untuk mengunjungi tujuan pariwisata berdasarkan kondisi iklim yang baik. Kondisi iklim yang baik adalah kondisi iklim yang memberikan efek positif bagi pengunjung sehingga potensi gangguan terhadap aktivitas pengunjung yang disebabkan parameter iklim relatif kecil, seperti contoh kegiatan dan aktivitas outdoor pengunjung akan lebih sedikit pada saat hujan dengan intensitas tinggi dibandingkan aktivitas outdoor pengunjung pada saat cerăh/tidak hujan.

Penerapan metode TCI pada dua Objek Wisata Malang Raya Jawa Timur yaitu Jatim Park 2 dan Taman Wisata Karangkates menjadi kajian yang menarik karena metode tersebut belum banyak digunakan di Indonesia. Data iklim yang digunakan adalah data dari Stasiun BMKG Karangploso untuk mewakili Objek Wisata Jatim Park 2 dan BMKG Karangkates untuk mewakili Objek Wisata Taman Wisata Karangkates. Pengolahan data tersebut menghasilkan pola nilai TCI bulanan di Taman Wisata Jatim Park 2 dan Karangkates periode 2000 hingga 2009.

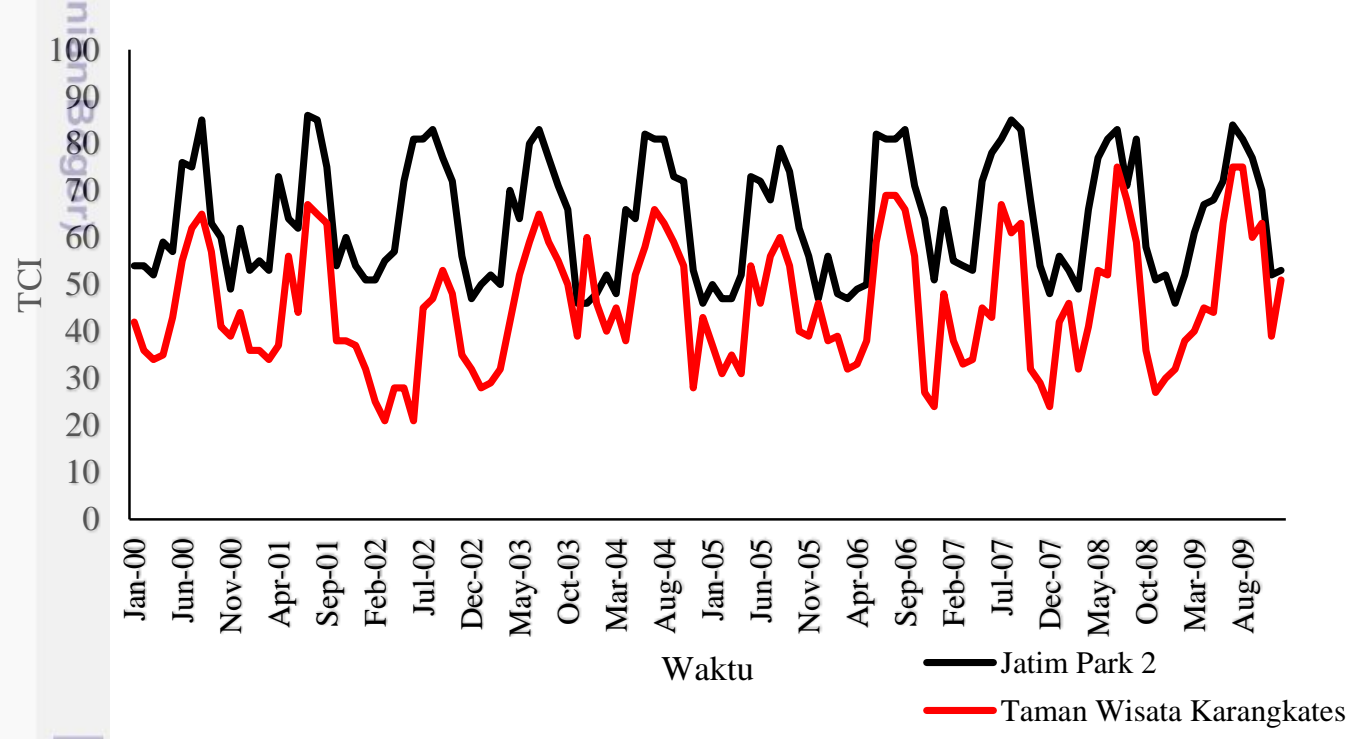

Gambar 3 Nilai TCI Taman Wisata Jatim Park 2 dan Karangkates tahun 2000-2009

Hasil pengolahan data pada Gambar 3 menunjukkan bahwa pola nilai TCI Jatim Park 2 dan Taman Wisata Karangkates periode 2000-2009 hampir sama. Nilai TCI tertinggi objek wisata Jatim Park 2 adalah 86 "Sangat bagus" dan nilai terendah 46 "Batas ditoleransi" sedangkan nilai TCI tertinggi objek wisata Karangkates adalah 75 "Baik" dan terendah adalah 21 "Sangat tidak baik". Nilai TCI Jatim Park 
2 relatif lebih tinggi dibandingkan Taman Wisata Karangkates sehingga dalam kurun waktu 10 tahun, kondisi iklim yang nyaman Jatim Park 2 cenderung lebih banyak dibandingkan Taman Wisata Karangkates. Perbedaan topografi ke dua Tobjek wisata mempengaruhi suhu udara dan curah hujan di kedua objek wisata. Jatim Park 2 berada di daerah dataran tinggi di bawah kaki Gunung Pandeman yang memiliki suhu khas pegunungan yang sejuk sedangkan Taman wisata Karangkates berada di dataran lebih rendah dengan suhu udara yang relatif tinggi. Gradien suhu berpengaruh terhadap suhu di dataran tinggi. Suhu yang tinggi akan mempengaruhi skema pemberian rating (Tabel 3). Perbedaan Nilai TCI di Jatim Park 2 dan Taman Wisata Karangkates disebabkan oleh suhu maksimum di Taman Wisata karang Kates terukur lebih tinggi sehingga rating yang dihasilkan rendah untuk kenyamanan pada siang hari (CID).

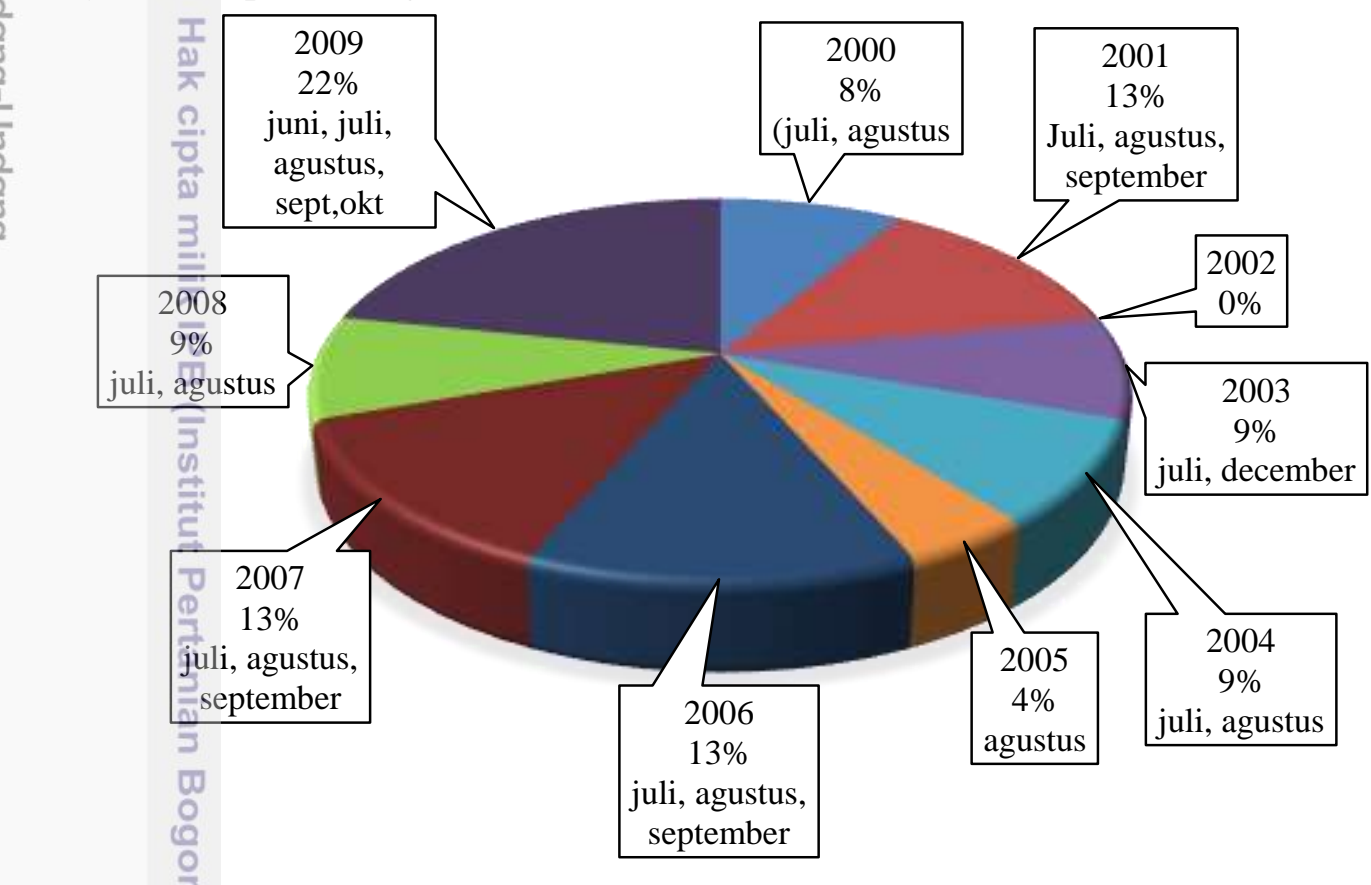

Gambar 4 Persentase jumlah bulan dengan kondisi iklim baik di Taman Wisata Karangkates Tahun 2000-2009; jumlah bulan $=120$

Hasil perhitungan nilai TCI di Taman Wisata Karangkates, sekitar 19.61\% (23 bulan) dikategorikan bulan dengan kondisi iklim yang nyaman untuk kunjungan pariwisata ke Taman Wisata Karangkates. tahun 2009 memiliki jumlah bulan terbanyak yang dikategorikan nyaman sebanyak 5 bulan. Sedangkan sepanjang tahun 2002 tidak tercapai kondisi iklim yang nyaman untuk berwisata. 


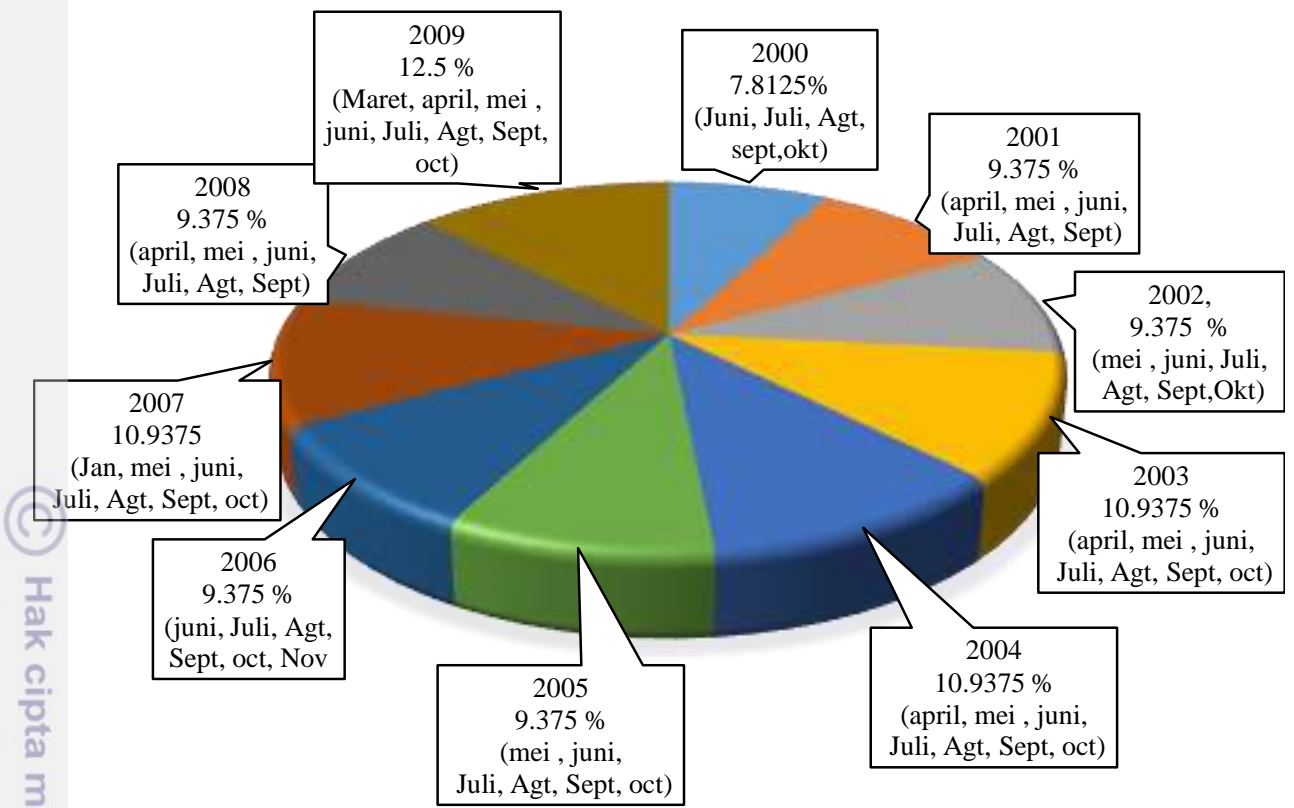

Gambar 5 Persentase jumlah bulan dengan kondisi iklim yang nyaman di wisata Jatim Park Tahun 2000-2009; jumlah bulan = 120 bulan.

Jatim Park 2 memiliki persentase lebih besar yaitu sekitar 53\% (64 bulan) dalam kurun waktu 10 tahun. Kondisi iklim yang nyaman berdasarkan nilai TCI mayoritas terjadi pada musim kemarau. Curah hujan cenderung tinggi pada musim hujān. Jumlah curah hujan bulanan yang tinggi di Jatim Park 2 dan daerah sekitarnya menyebabkan rating curah hujan menjadi relatif rendah. Sistim rating variabel curah hujan dalam TCI memiliki kelemahan karena skema rating curah hujan TCI yang dirancang di Eropa menggunakan data curah hujan di wilayah tersebut yang memiliki curah hujan relatif rendah dibandingkan curah hujan di daerah tropis, sehingga selang yang digunakan dalam skema rating curah hujan relatif kecil (0-150 mm). Curah hujan $150 \mathrm{~mm}$ atau $5 \mathrm{~mm} /$ hari merupakan curah hujan dengan kategori ringan (BMKG 2015). Hal tersebut seharusnya tidak terlalu berdampak buruk pada kegiatan dan aktivitas wisatawan. Selain itu, kelemahan lainnya yaitu tidak divalidasi dengan persepsi dari para wisatawan sehingga terkesan subjektif dalam penentuan rating.

Hasil perhitungan nilai TCI di Objek Wisata Karangkates dan Jatim Park 2 menunjukan bahwa periode (Juli Agustus) menjadi waktu yang disarankan untuk melakukan kunjungan pariwisata di Taman Wisata Karangkates dan periode JJA (Juni Juli Agustus) untuk kunjungan ke Jatim Park 2. Nilai TCI tinggi di kedua objek wisata pada musim kemarau menunjukan bahwa mayoritas bulan-bulan pada musim kemarau mengalami kondisi iklim yang baik untuk wisatawan dibandingkan dengan periode dimusim hujan karena:

1. Suhu udara dan curah hujan yang relatif rendah sehingga gangguan yang ditimbulkan dalam melakukan aktivitas pariwisata lebih kecil

2. Kecepatan angin yang lebih tinggi yang berpengaruh terhadap transport panas 
3. Lama penyinaran relatif lebih lama yang menandakan bahwa bulan tersebut memiliki keindahan dari aspek estetik yang baik.

Lama penyinaran mempengaruhi nilai TCI di Jatim Park 2 dan Taman Wisata $\frac{T}{2}$ Karangkates. Lama penyinaran memiliki hubungan dengan potensi kejadian hujan. Lama penyinaran dipengaruhi oleh sinar matahari yang mencapai permukaan bumi secara langsung maupun yang lolos dari penutupan awan. Hujan di suatu wilayah terjadi akibat adanya pembentukan awan konvektif karena penguapan dan naiknya masa udara ke atmosfer. Jika penutupan awan khususnya Awan Cumulunimbus banyak, lama penyinaran di wilayah tersebut cenderung pendek sedangkan potensi hujan menjadi besar. Hal tersebut menyebabkan curah hujan dan lama penyinaran di kedua objek wisata tersebut berbanding terbalik.

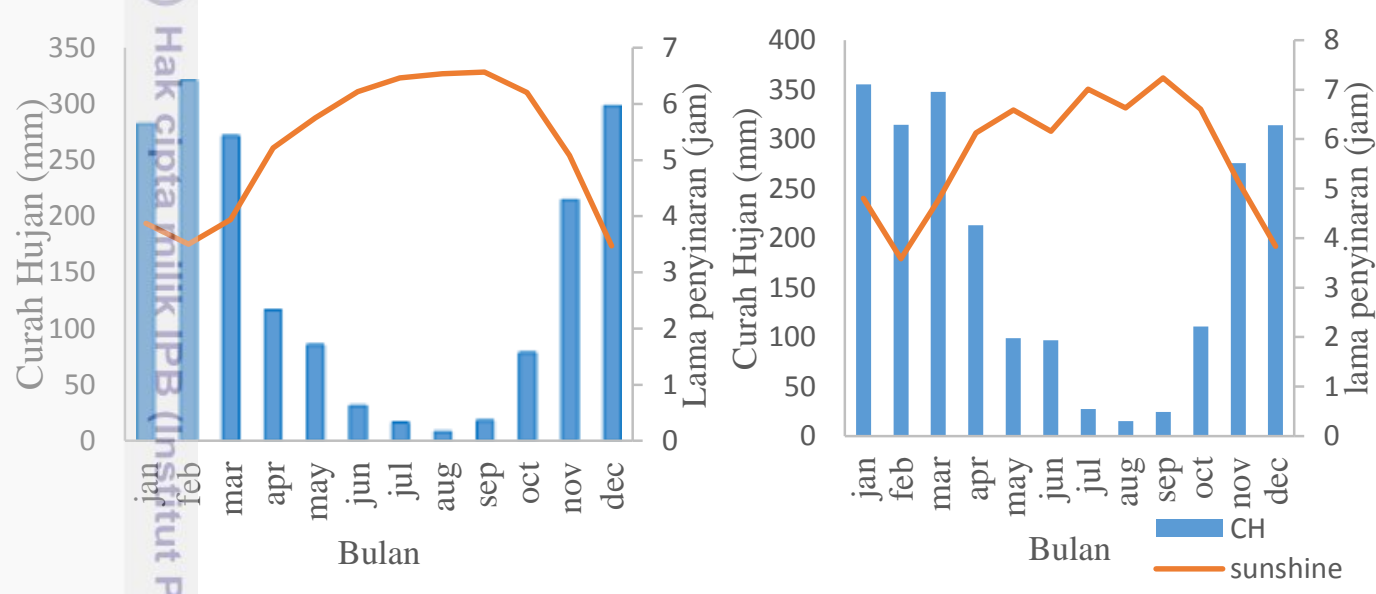

Gambar 6 Perbandingan curah hujan dan lama penyinaran Taman Wisata Jatim Park 2 (kiri) dan Karangkates (kanan) 2000-2009.

Grafik pada gambar 6 menunjukan bahwa periode musim hujan (Desember Januari Februari) curah hujan di wilayah kajian mengalami kenaikan dan lama penyinaran durasinya pendek. Lama penyinaran identik dengan kecerahan dan kejernihan atmosfer sehingga bulan DJF menjadi waktu yang kurang baik untuk melakukan aktivitas pariwisata. Potensi gangguan aktivitas pengunjung disebabkan hujan dengan intensitas tinggi cukup besar sehingga kepuasan yang dirasakan pengunjung menjadi kurang. Periode JJA (Juni Juli Agustus) menjadi periode yang paling baik untuk kunjungan pariwisata berdasarkan parameter lama penyinaran dan potensi gangguan dari hujan. Pada periode tersebut, curah hujan yang terjadi rendah akibat pengaruh dari angin muson timur. Angin muson timur merupakan angin yang disebabkan oleh posisi matahari yang berada di BBU yang bertiup mulai dari bulan April hingga September. Hal tersebut mengakibatkan di daerah Asia memiliki tekanan udara yang rendah akibat suhu yang tinggi sedangkan daerah Australia memiliki tekanan udara yang tinggi sehingga angin bertiup dari Australia ke Asia melewati Indonesia. Angin muson timur melewati gurun yang sangat luas di Australia sehingga bersifat kering. Oleh karena itu di Indonesia mengalami musim kemarau. 
Tabel 11 Nilai TCI berdasarkan data observasi Stasiun BMKG Karangploso dan Karangkates tahun 2000-2009

\begin{tabular}{|c|c|c|c|c|c|c|c|c|c|c|c|c|c|}
\hline \multirow{4}{*}{$\begin{array}{l}\bar{v} \\
\overline{0} \\
\bar{v}\end{array}$} & \multirow{2}{*}{ wilayah } & \multicolumn{12}{|c|}{ Bulan } \\
\hline & & Jan & Feb & Mar & Apr & May & Jun & Jul & Agt & Sep & Okt & Nov & Des \\
\hline & Jatim Park 2 & 53 & 52 & 52 & 61 & 66 & 77 & 80 & 81 & 76 & 65 & 54 & 51 \\
\hline & Karangkates & 38 & 36 & 34 & 36 & 47 & 50 & 65 & 63 & 59 & 46 & 34 & 39 \\
\hline
\end{tabular}

Kategori kenyamanan iklim

\begin{tabular}{|c|c|c|c|c|c|c|c|c|c|c|c|c|c|}
\hline id & \multicolumn{2}{|c|}{$\begin{array}{c}\text { Sangat } \\
\text { bagus }\end{array}$} & baik & $\begin{array}{c}\text { Cukup } \\
\text { baik }\end{array}$ & \multicolumn{2}{|c|}{$\begin{array}{c}\mathrm{Di} \\
\text { toleransi }\end{array}$} & \multicolumn{2}{|c|}{$\begin{array}{l}\text { Batas } \\
\text { di } \\
\text { toleransi }\end{array}$} & $\begin{array}{l}\text { Tidak } \\
\text { baik }\end{array}$ & $\begin{array}{c}\text { Sangat } \\
\text { Tidak } \\
\text { baik }\end{array}$ & \multicolumn{2}{|c|}{$\begin{array}{c}\text { Tidak } \\
\text { mungkin }\end{array}$} & \\
\hline $100(D)$ & 90 & 80 & 70 & & 60 & & 0 & 40 & 30 & & 0 & 10 & -9 \\
\hline
\end{tabular}

Tabel 6 merupakan penjelasan lebih detail dari grafik TCI pada Gambar 3. Kondisi nyaman dikategorikan kembali menjadi ideal, sangat baik, sangat baik dan baik. Pada periode 2000-2009, kondisi iklim yang nyaman untuk kegiatan pariwisata Jatim Park 2 terdapat pada bulan April hingga Oktober sedangkan di Taman Wisata Karangkates terjadi pada bulan Juli dan Agustus. Kondisi kenȳamanan iklim cenderung tidak tercapai pada musim hujan. Kejadian hujan dapat mengganggu aktivitas pengunjung untuk menikmati liburannya sehingga keptasan yang dihasilkan dari kegiatan pariwisata di kedua objek pariwisata menjadi kurang. Kepuasan ini berdasarkan pada tingkat aktivitas pariwisata yang dilakukan, jumlah biaya yang dikeluarkan, dan waktu yang dikorbankan untuk kegiatan pariwisata. Pengunjung mengeluarkan biaya selama periode waktu tertentu untuk berwisata dengan tujuan dapat menikmati fasilitas pariwisata sebanyak mungkin sehingga jika pengunjung memilih bulan Desember untuk kegiatan pariwisata dan di bulan Desember tersebut setiap harinya terjadi hujan maka secara teoritis aktivitas dan kepuasan yang dihasilkan akan rendah
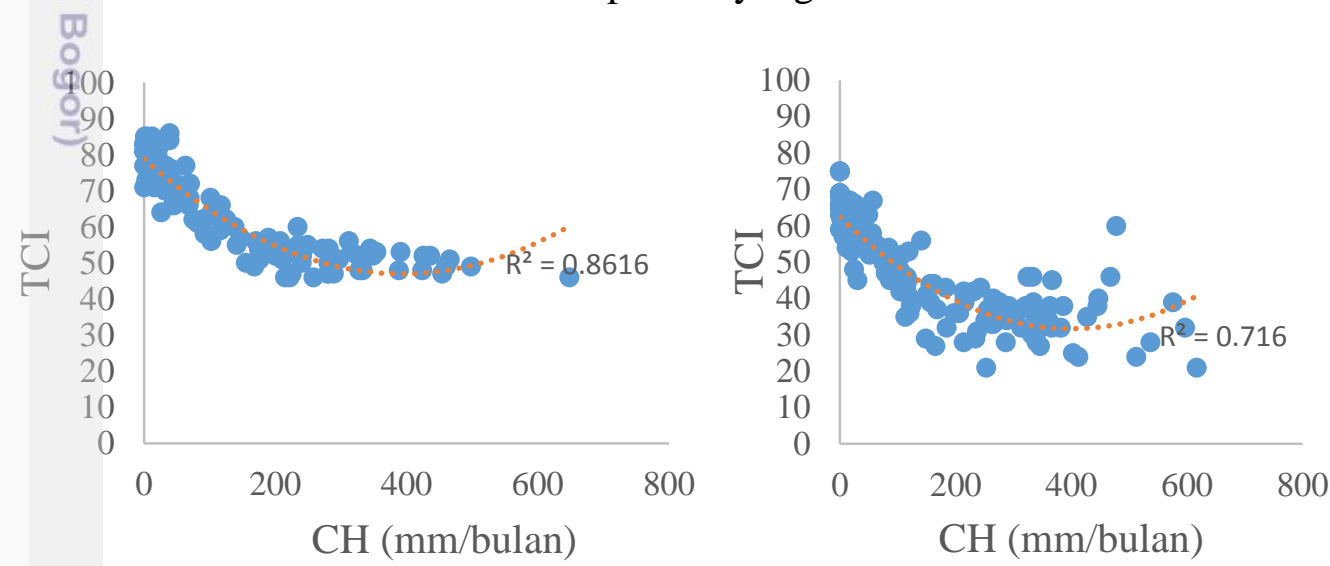

Gambar 7 Kontribusi CH terhadap nilai TCI Taman Wisata Jatim Park 2 (kiri) dan Karangkates (kanan) tahun 2000-2009; (Sumber: BMKG Karangploso dan Karangkates)

Curah hujan berpengaruh penting terhadap nilai TCI. Jika dilihat dari Gambar 7, curah hujan berkontribusi sebesar 86\% terhadap nilai TCI di kawasan Jatim Park 2 dan 71\% terhadap nilai TCI di Kawasan Taman Wisata Karangkates meski bobot curah hujan dalam TCI sebesar 20\%. Keragaman curah hujan di 


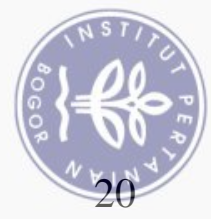

Indonesia yang tinggi menyebabkan hasil perhitungan TCI di setiap bulan menjadi sangat bervariasi. Semakin sering terjadi hujan dalam satu bulan, jumlah curah hujan bulanan akan semakin besar sehingga berpengaruh terhadap nilai TCI yang T akan menurun. Hubungan curah hujan terhadap nilai TCI secara polinomial memiliki ambang batas pada nilai $150 \mathrm{~mm}$. Curah hujan 0-149 $\mathrm{mm}$ memberikan efek penurunan nilai TCI yang tajam sedangkan $150 \mathrm{~mm}$ ke atas memberikan efek penurunan yang sama. Kelemahan perhitungan kenyamanan menggunakan suatu index adalah jika suatu variabel $\mathrm{x}$ mencapai ambang batas index, maka efek yang ditimbulkan terhadap variabel y akan sama dengan nilai variabel x yang lebih besar dari nilai ambang batasnya. Oleh karena itu, penentuan ambang batas variabel iklim dalam TCI khususnya curah hujan dalam penerapannya harus berbeda di setiap wilayah.

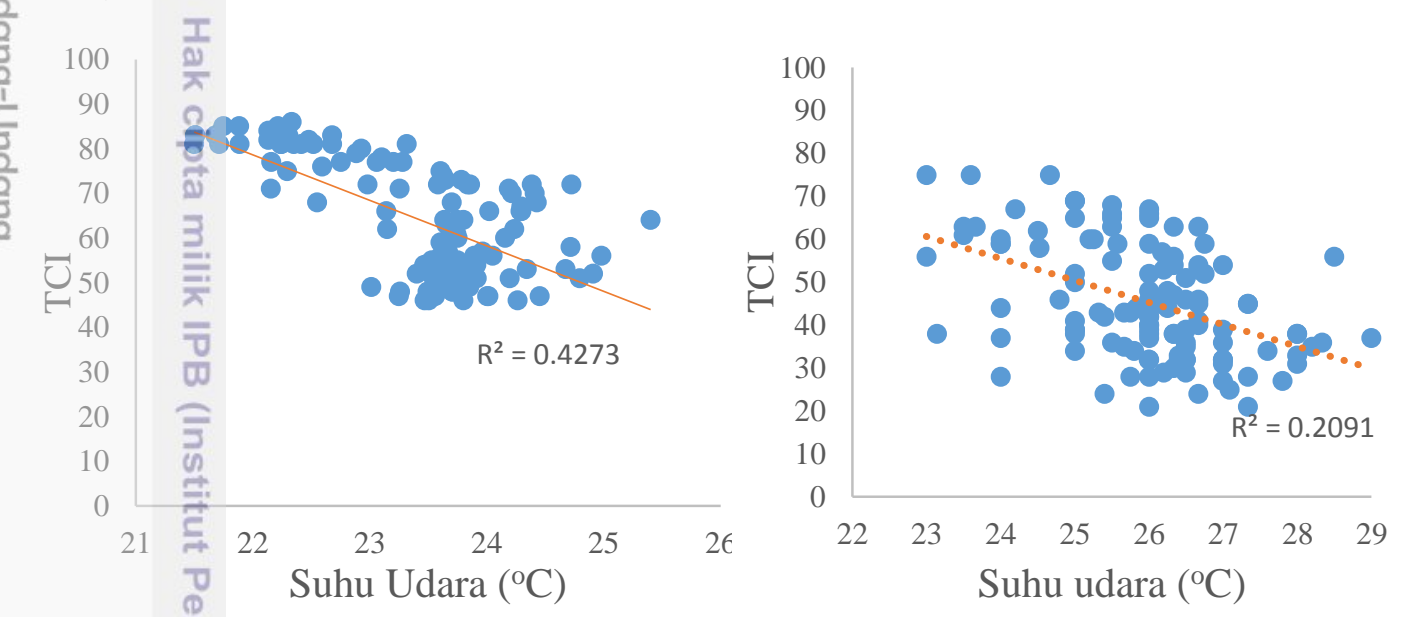

Gambar 8 Kontribusi suhu rata-rata $\left({ }^{\circ} \mathrm{C}\right)$ dan nilai TCI Taman Wisata Jatim Park 2

...(kiri) dan Karangkates (kanan) tahun 2000-2009; (Sumber: BMKG Karangploso dan Karangkates)

Pengaruh suhu terhadap nilai TCI tidak sebesar curah hujan jika dilihat dari nilai $R$-square. Meski bobot suhu sebesar 50 persen dari total nilai TCI, namun suhu hanya mampu menjelaskan sebesar $42 \%$ dari nilai TCI Jatim Park dan 20\% nilai TCI Taman Wisata Karangkates. Hal tersebut disebabkan oleh keragaman suhu di Jatim Park 2 dan Taman Wisata Karangkates yang tidak sebesar negara-negara di Eropa di mana metode TCI dirancang dan diterapkan. Teknik pembobotan TCI lebih besar pada parameter suhu yang dijelaskan dari nilai CID dan CIA dikarenakan variabilitas dan keragaman suhu di Eropa tinggi di setiap musimnya bahkan jumlah musim di Eropa bisa mencapai empat musim dengan suhu yang berbeda sedangkan di Indonesia yang berada di daerah Ekuator, hanya terdapat dua musim yaitu Musim Hujan dan Kemarau dengan suhu yang tidak terlalu berfluktuasi di setiap musimnya.

\section{Temperature Humidity Index}

Indeks kenyamanan manusia ditentukan oleh sensasi panas yang diterima oleh manusia dalam melakukan aktivitas. THI menjadi salah satu indikator kenyamanan manusia yang menitik beratkan pada suhu dan kelembaban relatif dimana metode ini telah banyak diterapkan di wilayah tropis. 
Gambar 9 merupakan pola grafik THI Jatim Park 2 dan Taman Wisata Karangkates. Garis Horizontal hitam dan merah merupakan batas kenyamanan. Menurut Effendy et al. (2006), pada umumnya di wilayah tropis manusia akan merasa nyaman pada nilai THI $20-26^{\circ} \mathrm{C}$ dan tidak nyaman pada THI di atas $26^{\circ} \mathrm{C}$ (terlalu panas). THI menggunakan dua parameter iklim yaitu suhu dan kelembaban rata-rata. Kelemahan THI adalah tidak memperhitungkan parameter iklim lainnya seperti curah hujan (Emmanuel 2005).

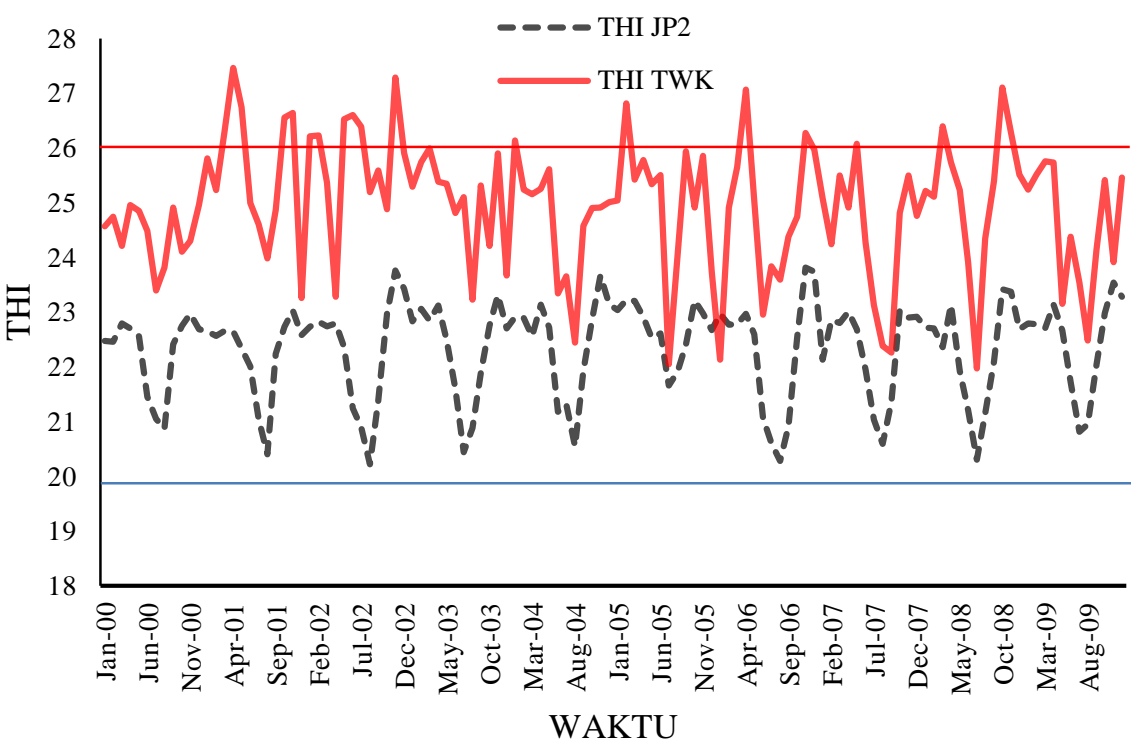

Gam̄bar 9 Nilai THI Jatim Park 2 (500-600 mdpl) dan Taman wisata Karangkates (200-300 mdpl) tahun 2000-2009

Hasil analisis menyatakan bahwa tahun 2000-2009 kondisi iklim di wilayah Jatim Park 2 berada pada kondisi nyaman pada selang 21 hingga 24. Nilai THI tertinggi selama periode 2000-2009 terjadi pada November 2006 yaitu bernilai 23.86 dan terendah terjadi pada bulan Agustus 2002 bernilai 20.22. Berdasarkan nilai THI, Wilayah Taman Wisata Karangkates terdapat 19 bulan yang dikategorikan kurang nyaman (THI>26) pada periode 2000-2009. Nilai THI tertinggi terjadi pada bulan April 2001 yang bernilai 27,46 sedangkan THI terendah terjadi pada bulan Juli 2008 yang bernilai 21.97. Mengacu pada pola grafik THI diatas, mayoritas aspek termal Taman wisata Karangkates dan Jatim Park 2 dikategorikan nyaman untuk kegiatan dan aktivitas pariwisata. Kegiatan pariwisata lebih baik dilakukan di bulan-bulan pada musim kemarau untuk menghindari hujan karena selain dapat mengganggu aktivitas wisata khususnya aktivitas outdoor, pada periode musim hujan suhu udara cenderung lebih tinggi dan hujan akan mengakibatkan kelembaban udara menjadi tinggi karena penguapan sehingga sensasi panas dan gerah yang dirasakan akan semakin terasa dan membuat tidak nyaman.

\section{Holiday Climate Index}

Holiday Climate index (HCI) adalah indeks iklim yang dirancang dengan meminimalisasi kekurangan dari indeks TCI. Gambar 10 merupakan grafik nilai HCI objek wisata Taman Wisata Karangkates dan Jatim Park 2 tahun 2000 hingga 
2009. Berbeda dengan hasil skor TCI, selisih skor HCI musim kemarau dan hujan relatif rendah. Nilai HCI terendah mayoritas terjadi pada musim hujan yaitu periode DJF sedangkan HCI tertinggi mayoritas terjadi pada periode musim kemarau (JJA).

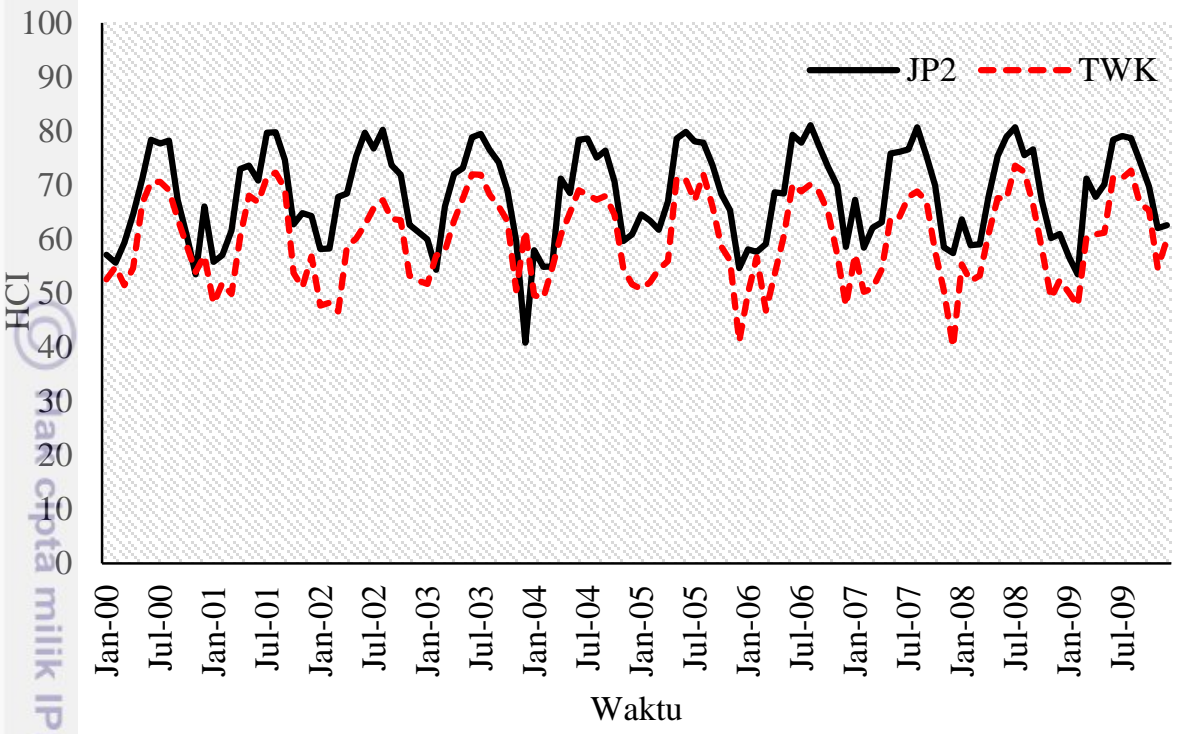

Jika dibandingkan dengan skor TCI, HCI memberikan skor yang lebih baik dibandingkan skor TCI di kedua objek wisata. Nilai HCI terendah Jatim Park 2 tahun 2000 hingga 2009 adalah 41 dengan kategori "Batas ditoleransi" dan nilai HCI tertinggi adalah 81 dengan kategori "Sangat bagus". Objek wisata Taman Wisata Karangkates memiliki nilai HCI terendah adalah 40 kategori "batas ditoleransi" dan tertinggi adalah 74 kategori "Baik". HCI memberikan nilai yang lebih layak pada kondisi iklim yang dianggap buruk pada indeks TCI dan pada kondisi iklim yang dianggap sangat baik pada indeks TCI. Hal ini disebabkan karena HCI memberikan bobot yang seimbang pada aspek termal, estetika dan fisik sehingga kondisi iklim yang sangat baik atau sangat buruk tidak akan mudah tercapai jika tidak semua aspek tersebut menyatakan pada kondisi baik/buruk.
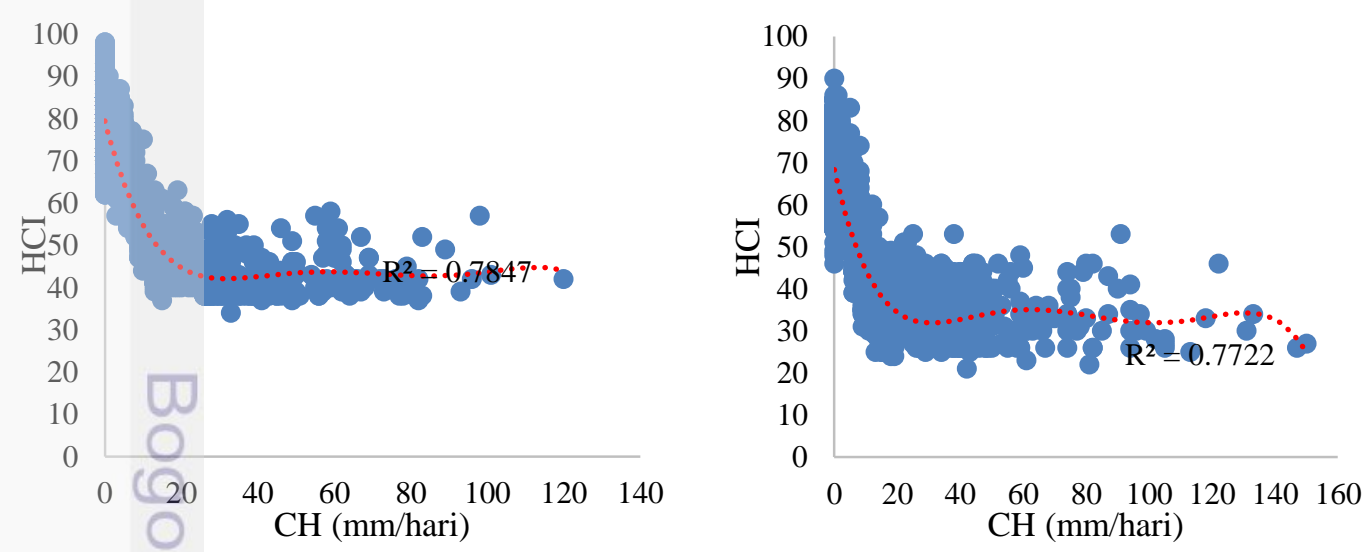

Gambar 11 Kontribusi CH terhadap nilai HCI Taman Wisata Jatim Park 2 (kiri) dan Karangkates (kanan) tahun 2000-2009; (Sumber: BMKG Karangploso dan Karangkates) 
Gambar 11 menunjukan kontribusi curah hujan terhadap nilai HCI di Taman Wisata Jatim Park 2 dan Karangkates. Kontribusi $\mathrm{CH}$ di kedua wilayah kajian hampir sama yaitu 78\% di Jatim Park 2 dan 77\% di Taman Wisata Karangkates. Kontribusi curah hujan pada grafik secara polinomial menunjukan bahwa peningkatan curah hujan hingga $20 \mathrm{~mm}$ per hari, akan memberikan efek penurunan skor HCI yang tajam sedangkan peningkatan curah hujan diatas $20 \mathrm{~mm}$ akan memberikan efek penurunan yang relatif landai terhadap nilai HCI. Nilai ambang batas curah hujan pada HCI relatif lebih kecil dibandingkan pada TCI. Hal ini dikarenakan data yang digunakan dalam HCI merupakan data harian sehingga perhitungan dan skala rating yang digunakan berdasarkan data curah hujan harian. Ambang batas curah hujan menunjukan bahwa curah hujan sebesar $20 \mathrm{~mm}$ dalam satu hari memberikan efek yang buruk terhadap aktivitas dan kegiatan pariwisata. Hatini berkaitan dengan intensitas dan kategori hujan dimana curah hujan sebesar $20 \mathrm{~mm}$ dikategorikan hujan yang normal jika berdurasi 24 jam, namun jika durasi 3-4jam kategorinya menjadi hujan lebat sehingga dapat memberikan efek buruk bagi wisatawan.
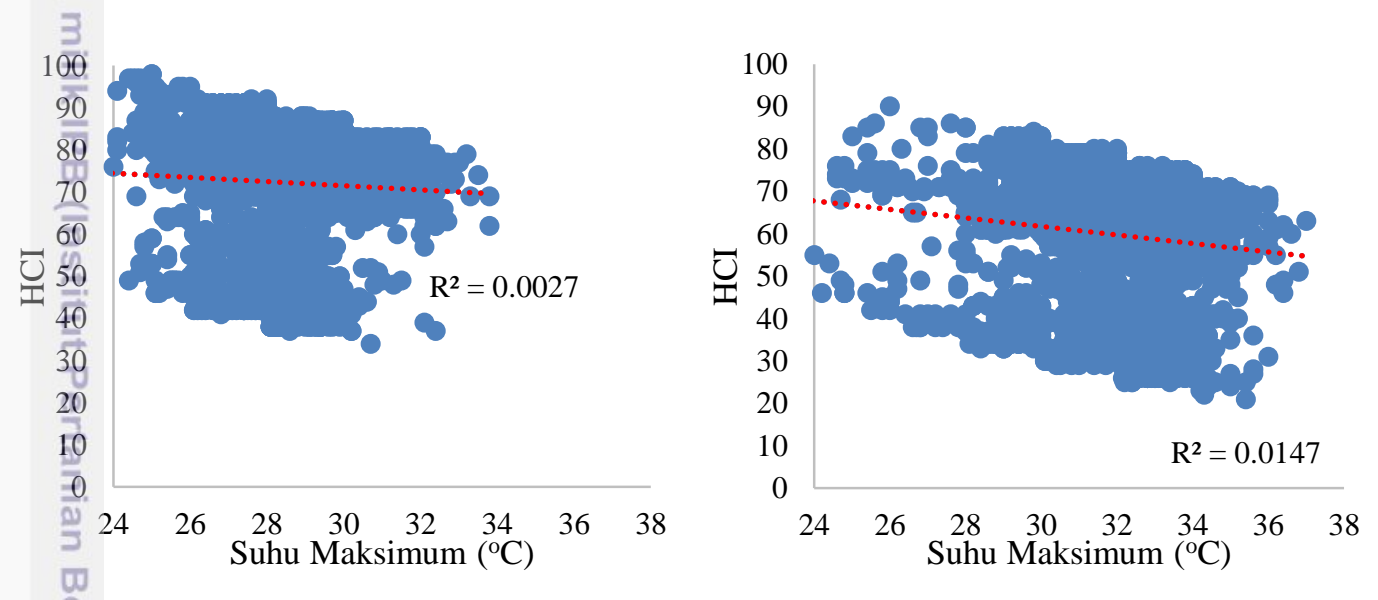

Gambar 12 Kontribusi suhu udara terhadap nilai HCI Taman Wisata Jatim Park 2 (kiri) dan Karangkates (kanan) tahun 2000-2009; (Sumber: BMKG Karangploso dan Karangkates)

Kontribusi suhu udara terhadap skor HCI di kedua objek wisata relatif kecil. Berdasarkan Gambar 12, persentase kontribusi suhu udara dibawah 5\%. Suhu udara relatif sama dan variabilitasnya kecil di kedua objek wisata sepanjang tahun 2000 hingga 2009 sehingga nilai suhu yang sama akan memberikan pengaruh yang berbeda terhadap nilai HCI. Hal tersebut bergantung pada pengaruh variabel lain dimana pengaruh terbesar nilai HCI dipengaruhi oleh curah hujan yang bervariatif setiap musim.

\section{Perbandingan THI, TCI dan HCI}

Indeks iklim Holiday Climate Index merupakan index iklim yang dirancang untuk mengatasi kekurangan pada indeks iklim Tourism Climate Index. Perbedaan hasil dari nilai THI, TCI dan HCI di ke dua objek wisata akan menunjukan metode yang lebih valid. Perbandingan THI, TCI dan HCI disajikan dengan menggambarkan kategori kenyamanan di Taman Wisata Karangkates dan Jatim Park 2. 
Tabel 12 Skor THI, TCI dan HCI bulanan objek wisata Taman Wisata Karangkates

\begin{tabular}{|c|c|c|c|c|c|c|c|c|c|c|c|c|c|}
\hline \multirow{2}{*}{ Tahun } & \multirow{2}{*}{ Metode } & \multicolumn{12}{|c|}{ Bulan } \\
\hline & & Jan & Feb & Mar & Apr & Mei & Jun & Jul & Agt & Sep & Okt & Nov & Des \\
\hline \multirow{3}{*}{2000} & THI & 24.57 & 24.74 & 24.21 & 24.95 & 24.85 & 24.48 & 23.40 & 23.81 & 24.91 & 24.10 & 24.30 & 24.96 \\
\hline & TCI & 42 & 36 & 34 & 35 & 43 & 55 & 62 & 65 & 57 & 41 & 39 & 44 \\
\hline & $\mathrm{HCI}$ & 53 & 55 & 52 & 55 & 67 & 71 & 71 & 69 & 64 & 59 & 54 & 57 \\
\hline \multirow{3}{*}{2001} & THI & 25.81 & 25.23 & 26.29 & 27.46 & 26.75 & 25.00 & 24.60 & 23.98 & 24.87 & 26.55 & 26.64 & 23.26 \\
\hline & TCI & 36 & 36 & 34 & 37 & 56 & 44 & 67 & 65 & 63 & 38 & 38 & 37 \\
\hline & $\mathrm{HCI}$ & 48 & 52 & 50 & 61 & 68 & 67 & 71 & 72 & 69 & 54 & 51 & 57 \\
\hline \multirow{3}{*}{2002} & $\mathrm{THI}$ & 26.21 & 26.23 & 25.37 & 23.28 & 26.52 & 26.60 & 26.39 & 25.19 & 25.58 & 24.88 & 27.29 & 25.91 \\
\hline & $\mathrm{TCI}$ & 32 & 25 & 21 & 28 & 28 & 21 & 45 & 47 & 53 & 48 & 35 & 32 \\
\hline & $\mathrm{HCI}$ & 48 & 48 & 47 & 59 & 60 & 63 & 66 & 67 & 64 & 64 & 53 & 52 \\
\hline \multirow{3}{*}{2003} & FHI & 25.29 & 25.74 & 25.99 & 25.38 & 25.34 & 24.81 & 25.10 & 23.23 & 25.32 & 24.21 & 25.90 & 23.67 \\
\hline & $\mathrm{TCI}$ & 28 & 29 & 32 & 42 & 52 & 59 & 65 & 59 & 55 & 50 & 39 & 60 \\
\hline & $\mathrm{HCI}$ & 52 & 57 & 58 & 63 & 68 & 72 & 72 & 68 & 66 & 63 & 51 & 62 \\
\hline \multirow{3}{*}{2004} & THI & 26.14 & 25.23 & 25.15 & 25.25 & 25.61 & 23.34 & 23.66 & 22.45 & 24.57 & 24.90 & 24.91 & 25.01 \\
\hline & TCI & 46 & 40 & 45 & 38 & 52 & 58 & 66 & 63 & 59 & 54 & 28 & 43 \\
\hline & $\overline{\mathrm{HCI}}$ & 50 & 49 & 55 & 61 & 65 & 69 & 68 & 67 & 68 & 65 & 55 & 52 \\
\hline \multirow{3}{*}{2005} & THI & 25.04 & 26.81 & 25.42 & 25.78 & 25.34 & 25.51 & 22.04 & 24.04 & 25.94 & 24.91 & 25.85 & 23.74 \\
\hline & TCI & 37 & 31 & 35 & 31 & 54 & 46 & 56 & 60 & 54 & 40 & 39 & 46 \\
\hline & $\mathrm{HCI}$ & 51 & 52 & 54 & 56 & 71 & 71 & 67 & 72 & 66 & 59 & 56 & 49 \\
\hline \multirow{3}{*}{2006} & THI & 22.13 & 24.91 & 25.65 & 27.06 & 25.03 & 22.96 & 23.84 & 23.60 & 24.38 & 24.74 & 26.27 & 25.96 \\
\hline & TCI & 38 & 39 & 32 & 33 & 38 & 59 & 69 & 69 & 66 & 56 & 27 & 24 \\
\hline & $\mathrm{HCI}$ & 50 & 57 & 47 & 54 & 61 & 70 & 69 & 70 & 69 & 65 & 57 & 52 \\
\hline \multirow{3}{*}{2007} & THI & 25.08 & 24.24 & 25.50 & 24.91 & 26.08 & 24.27 & 23.13 & 22.38 & 22.26 & 24.81 & 25.49 & 24.76 \\
\hline & TCI & 48 & 38 & 33 & 34 & 45 & 43 & 67 & 61 & 63 & 32 & 29 & 24 \\
\hline & $\mathrm{HCI}$ & 57 & 50 & 51 & 54 & 64 & 64 & 71 & 69 & 67 & 58 & 50 & 40 \\
\hline \multirow{3}{*}{2008} & THI & 25.21 & 25.11 & 26.40 & 25.73 & 25.23 & 23.92 & 21.97 & 24.35 & 25.39 & 27.10 & 26.27 & 25.51 \\
\hline & $\mathrm{FCI}$ & 42 & 46 & 32 & 41 & 53 & 52 & 75 & 68 & 59 & 36 & 27 & 30 \\
\hline & $\mathrm{HCI}$ & 55 & 52 & 53 & 61 & 68 & 67 & 74 & 72 & 66 & 58 & 49 & 52 \\
\hline \multirow{3}{*}{2009} & THI & 25.24 & 25.51 & 25.75 & 25.73 & 23.15 & 24.38 & 23.54 & 22.48 & 24.14 & 25.41 & 23.92 & 25.46 \\
\hline & $\mathrm{TCI}$ & 32 & 38 & 40 & 45 & 44 & 63 & 75 & 75 & 60 & 63 & 39 & 51 \\
\hline & $\mathrm{HCI}$ & 50 & 48 & 60 & 61 & 61 & 72 & 70 & 73 & 67 & 65 & 55 & 60 \\
\hline
\end{tabular}

\section{\begin{tabular}{l|l|l} 
Nyaman & Netral (ditoleransi) & Tidak nyaman
\end{tabular}}

Tabel 12 merupakan perbandingan skor THI, TCI dan HCI tahun 2000 hingga 2009. Kondisi kenyamanan iklim Taman Wisata Karangkates mengalami puncak nilai kenyamanan (THI, TCI dan HCI) mayoritas pada bulan musim kemarau (Juli, Agustus). Hal ini menunjukan bahwa bulan Juli dan Agustus mayoritas memiliki kondisi yang nyaman dan cocok untuk kegiatan pariwisata di Taman Wisata Karangkates sepanjang tahun 2000-2009. Nilai HCI tertinggi terjadi pada Juli 2008 dengan nilai 74 sedangkan nilai TCI tertinggi terjadi pada bulan Juli dan Agustus 2009 dengan nilai 75 kategori "baik". Namun kondisi kenyamanan Taman Wisata Karangkates berdasarkan skor HCI cenderung tidak berfluktuasi dibandingkan kenyamanan berdasarkan skor TCI. Hal ini disebabkan karena kelemahan TCI yang mémberikan bobot pada suhu udara sebesar 50\%. Suhu udara di Taman wisata 
Karangkates yang relatif tinggi menyebabkan rating yang dihasilkan rendah. Selain itu jumlah curah hujan yang tinggi menyebabkan nilai TCI di Taman Wisata Karangkates menjadi rendah di musim penghujan. Grafik CID dan CIA dinyatakan handal untuk kisaran suhu 20-27 dan kelembaban relatif 30-70 (Heurtier 1968). Sedangkan suhu di Taman Wisata karangkates berada pada kisaran suhu rataan 23$29^{\circ} \mathrm{C}$ dan kelembaban relatif $63-93 \%$ sehingga penggunaan grafik CID dan CIA untuk menentukan kenyamanan harian dan siang hari kurang tepat. Hal ini menunjukan kelemahan TCI jika diterapkan di daerah yang memiliki suhu dan curah hujan yang tinggi.

Tabel 13 Skor THI, TCI dan HCI bulanan objek wisata Jatim Park 2

\begin{tabular}{|c|c|c|c|c|c|c|c|c|c|c|c|c|c|}
\hline \multirow{2}{*}{$\begin{array}{c}\text { Tahun } \\
I\end{array}$} & \multirow{2}{*}{ Metode } & \multicolumn{12}{|c|}{ Bulan } \\
\hline & & Jan & $\mathrm{Feb}$ & Mar & Apr & Mei & Jun & Jul & Agt & Sep & Okt & Nov & Des \\
\hline$\frac{1}{\lambda}$ & THI & 22.48 & 22.46 & 22.79 & 22.70 & 22.55 & 21.45 & 21.05 & 20.87 & 22.41 & 22.74 & 22.97 & 22.69 \\
\hline $2000 \Omega$ & TCI & 54 & 54 & 52 & 59 & 57 & 76 & 75 & 85 & 63 & 60 & 49 & 62 \\
\hline 음 & $\mathrm{HCI}$ & 57 & 56 & 59 & 65 & 71 & 78 & 78 & 78 & 67 & 61 & 54 & 66 \\
\hline$=$ & THI & 22.65 & 22.56 & 22.65 & 22.65 & 22.34 & 22.01 & 21.06 & 20.41 & 22.24 & 22.72 & 23.02 & 22.57 \\
\hline 2001 三. & TCI & 53 & 55 & 53 & 73 & 64 & 62 & 86 & 85 & 75 & 54 & 60 & 54 \\
\hline $\bar{\lambda}$ & $\mathrm{HCI}$ & 56 & 57 & 62 & 73 & 74 & 71 & 80 & 80 & 75 & 63 & 65 & 64 \\
\hline $\bar{\nabla}$ & THI & 22.73 & 22.82 & 22.74 & 22.79 & 22.37 & 21.24 & 20.90 & 20.22 & 21.39 & 22.97 & 23.75 & 23.42 \\
\hline 2002 & TCI & 51 & 51 & 55 & 57 & 72 & 81 & 81 & 83 & 77 & 72 & 56 & 47 \\
\hline 5 & $\mathrm{HCI}$ & 58 & 58 & 68 & 68 & 75 & 80 & 77 & 80 & 74 & 72 & 63 & 61 \\
\hline$\Rightarrow$ & THI & 22.83 & 23.05 & 22.84 & 23.12 & 22.50 & 21.60 & 20.45 & 20.88 & 21.89 & 22.75 & 23.31 & 22.70 \\
\hline 2003 & $\mathrm{TCI}$ & 50 & 52 & 50 & 70 & 64 & 80 & 83 & 77 & 71 & 66 & 46 & 46 \\
\hline${ }^{\top}$ & $\mathrm{HCI}$ & 60 & 54 & 66 & 72 & 73 & 79 & 80 & 77 & 74 & 69 & 60 & 41 \\
\hline & THI & 22.90 & 22.89 & 22.56 & 23.13 & 22.72 & 21.18 & 21.32 & 20.55 & 21.92 & 22.87 & 23.66 & 23.14 \\
\hline $2004=$ & TCI & 48 & 52 & 48 & 66 & 64 & 82 & 81 & 81 & 77 & 68 & 53 & 46 \\
\hline (2) & $\mathrm{HCI}$ & 58 & 55 & 55 & 71 & 69 & 78 & 79 & 75 & 76 & 71 & 60 & 61 \\
\hline & THI & 23.03 & 23.22 & 23.20 & 22.90 & 22.53 & 22.61 & 21.66 & 21.92 & 22.41 & 23.21 & 22.97 & 22.67 \\
\hline 2005 & TCI & 50 & 47 & 47 & 52 & 73 & 72 & 68 & 79 & 74 & 62 & 56 & 47 \\
\hline & $\mathrm{HCI}$ & 65 & 63 & 62 & 67 & 79 & 80 & 78 & 78 & 74 & 68 & 65 & 55 \\
\hline \multirow{3}{*}{2006} & THI & 22.96 & 22.76 & 22.77 & 22.97 & 22.60 & 21.07 & 20.61 & 20.28 & 20.92 & 22.54 & 23.81 & 23.73 \\
\hline & TCI & 56 & 48 & 47 & 49 & 50 & 82 & 81 & 81 & 83 & 71 & 64 & 51 \\
\hline & $\mathrm{HCI}$ & 58 & 58 & 59 & 69 & 68 & 79 & 78 & 81 & 79 & 73 & 70 & 59 \\
\hline \multirow{3}{*}{2007} & THI & 22.13 & 22.85 & 22.79 & 23.01 & 22.68 & 21.95 & 21.04 & 20.60 & 21.37 & 23.03 & 22.90 & 22.90 \\
\hline & TCI & 62 & 51 & 54 & 53 & 72 & 78 & 81 & 85 & 83 & 68 & 54 & 48 \\
\hline & $\mathrm{HCI}$ & 67 & 58 & 62 & 63 & 76 & 76 & 77 & 81 & 75 & 70 & 59 & 57 \\
\hline \multirow{3}{*}{2008} & THI & 22.72 & 22.70 & 22.36 & 23.13 & 21.93 & 21.21 & 20.30 & 21.15 & 22.09 & 23.41 & 23.37 & 22.68 \\
\hline & TCI & 52 & 53 & 49 & 66 & 73 & 81 & 83 & 71 & 81 & 58 & 51 & 52 \\
\hline & $\mathrm{HCI}$ & 64 & 59 & 59 & 68 & 75 & 79 & 81 & 76 & 77 & 67 & 60 & 61 \\
\hline \multirow{3}{*}{2009} & THI & 22.79 & 22.79 & 22.71 & 23.13 & 22.67 & 21.72 & 20.82 & 20.96 & 22.03 & 22.98 & 23.52 & 23.28 \\
\hline & TCI & 46 & 52 & 61 & 67 & 64 & 80 & 84 & 81 & 77 & 70 & 52 & 53 \\
\hline & $\mathrm{HCI}$ & 57 & 54 & 71 & 68 & 70 & 78 & 79 & 79 & 74 & 70 & 62 & 63 \\
\hline & \multicolumn{3}{|c|}{ Nyaman } & \multicolumn{5}{|c|}{ Netral (ditoleransi) } & \multicolumn{5}{|c|}{ Tidak nyaman } \\
\hline
\end{tabular}

Kondisi kenyamanan berdasarkan Skor THI, TCI dan HCI Jatim Park 2 cenderung lebih baik dibandingkan wilayah Taman Wisata Karangkates. Nilai THI Jatim Park berada pada rentan 20.22 hingga 23.81 sehingga menurut kategori THI 
aspek termal Jatim Park 2 nyaman pada periode 2000-2009. Berdasarkan nilai HCI, kondisi kenyamanan Jatim Park 2 mayoritas cukup baik (HCI>60) dan 22 bulan yang dikategorikan "Ditoleransi". Berdasarkan nilai TCI, musim kemarau (JuniSeptember) menjadi kondisi kenyamanan terbaik untuk pariwisata sedangkan sisanya berada pada kondisi iklim "Ditoleransi". Kondisi iklim "Ditoleransi" bukan berarti kondisi kenyamanan di daerah tersebut tidak layak untuk kegiatan pariwisata melainkan kondisi iklim tersebut dapat terasa nyaman dengan melakukan beberapa solusi. Seperti menggunakan baju yang dapat menyerap keringat dan berwarna putih pada saat siang hari atau menggunakan jaket pada saat suhu udara terasa dingin.

Nilai TCI cenderung lebih rendah dibandingkan nilai HCI pada periode musim hujan (Oktober-Maret) di kedua objek pariwisata terutama di Taman Wisata Karangkates yang memiliki suhu udara yang tinggi. TCI menitikberatkan nilai kenyamanan pada aspek termal sedangkan HCI menitik beratkan pada ketiga aspeknyassecara seimbang yaitu fisik, estetik dan termal. Ketika suhu udara tinggi, peringkat TCI akan cenderung langsung menurun karena bobot dari parameter lainnya kecil sehingga skor TCI rendah. Berbeda dengan HCI, pembobotan HCI dianggap tinggi, nilai HCI tidak lebih rendah dari nilai TCI karena terdapat pengaruh dari aspek fisik dan estetiknya.

Berikut ini adalah perbandingan perbedaan nilai HCI dan TCI pada Kondisi iklim berbeda menggunakan ilustrasi kondisi yaitu pada musim hujan yang identik dengan keawanan dan curah hujan yang tinggi sedangkan musim kemarau yang identik dèngan curah hujan dan tingkat keawanan yang rendah. Tujuan dari ilustrasi kondisi im adalah untuk menguji sensitivitas dari rancangan indeks iklim (peringkat setiap parameter dan bobot setiap parameter) masing-masing metode.

Tabel 14 Nilai TCI dan HCI pada ilustrasi musim hujan dan kemarau di Taman wWisata Karangkates

\begin{tabular}{|c|c|c|c|c|c|c|c|c|c|c|c|c|}
\hline \multirow[b]{3}{*}{ Index } & \multirow{3}{*}{ 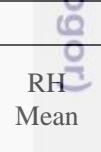 } & \multirow{3}{*}{$\begin{array}{l}\mathrm{RH} \\
\mathrm{min}\end{array}$} & \multicolumn{7}{|c|}{ Musim Hujan } & \multirow{2}{*}{\multicolumn{2}{|c|}{ Fisik }} & \multirow[b]{3}{*}{ Skor } \\
\hline & & & & & Sunshine & & Wind & Termal & Estetik & & & \\
\hline & & & $\begin{array}{c}1 \\
\max \end{array}$ & mean & $\begin{array}{c}\text { /Cloud } \\
(\%)\end{array}$ & $\mathrm{mm}$ & $\begin{array}{l}(\mathrm{km} / \\
\mathrm{jam})\end{array}$ & CID CIA & $\begin{array}{c}\text { sunshine } \\
\text { cloud/ }\end{array}$ & $\mathrm{CH}$ & wind & \\
\hline \multirow{2}{*}{ TCI } & \multirow{2}{*}{83} & \multirow{2}{*}{70} & \multirow{2}{*}{31.5} & \multirow{2}{*}{26.6} & \multirow{2}{*}{3.9} & \multirow{2}{*}{242} & \multirow{2}{*}{6.38} & $1.5 \quad 3.5$ & 1.5 & 0 & 4 & \\
\hline & & & & & & & & 19 & 6 & 0 & 8 & 33 \\
\hline \multirow{2}{*}{ HCI } & \multirow{2}{*}{83} & \multirow{2}{*}{70} & \multirow{2}{*}{31.5} & \multirow{2}{*}{26.6} & \multirow{2}{*}{81} & \multirow{2}{*}{8} & \multirow{2}{*}{6.38} & 4 & 3 & 5 & 10 & \\
\hline & & & & & & & & 16 & 6 & 15 & 10 & 47 \\
\hline \multicolumn{13}{|c|}{ Musim Kemarau } \\
\hline \multirow[b]{2}{*}{ Index } & \multirow{2}{*}{$\begin{array}{c}\text { RH } \\
\text { Mean }\end{array}$} & \multirow{2}{*}{$\begin{array}{l}\text { RH } \\
\text { min }\end{array}$} & \multirow{2}{*}{$\begin{array}{c}\mathrm{T} \\
\max \end{array}$} & \multirow{2}{*}{$\begin{array}{c}\mathrm{T} \\
\text { mean }\end{array}$} & \multirow{2}{*}{$\begin{array}{l}\text { Cloud } \\
(\%)\end{array}$} & \multirow{2}{*}{$\begin{array}{c}\mathrm{CH} \\
(\mathrm{mm} \\
)\end{array}$} & \multirow{2}{*}{$\begin{array}{l}\text { Wind } \\
(\mathrm{km} / \\
\mathrm{jam})\end{array}$} & termal & estetik & \multicolumn{2}{|c|}{ fisik } & \multirow[b]{2}{*}{ Skor } \\
\hline & & & & & & & & CID CIA & $\begin{array}{c}\text { cloud/ } \\
\text { sunshine }\end{array}$ & $\mathrm{CH}$ & wind & \\
\hline TCI & 78 & 66 & 31 & 256 & 57 & 70 & 854 & $2 \quad 4.5$ & 4.5 & 4 & 4 & \\
\hline $1 C 1$ & 18 & 60 & 31 & 25.0 & 5.1 & 19 & 8.54 & 25 & 18 & 16 & 8 & 67 \\
\hline WC & & 66 & 31 & 25 & 53 & 3 & & 5 & 6 & 8 & 10 & \\
\hline HCI & & 00 & 31 & 25.0 & 53 & 3 & 8.54 & 20 & 12 & 24 & 10 & 66 \\
\hline
\end{tabular}

Berdasarkan tabel 14, nilai HCI dan TCI pada ilustrasi di musim hujan memiliki selisih sekitar 14. Indeks HCI memberikan skor yang lebih besar yaitu 47 kategori "Batas ditoleransi' dibandingkan dengan TCI yang memberikan nilai 33 kategori "Tidak baik" pada musim hujan. Padahal curah hujan $242 \mathrm{~mm}$ atau $8 \mathrm{~mm}$ per harinya adalah curah hujan dengan intensitas ringan sehingga tidak terlalu 
mengganggu aktivitas wisatawan. Perbedaan ini disebabkan oleh pemberian rating parameter curah hujan di indeks TCI terlalu kecil. HCI memberikan rating 5 untuk nilai curah harian sebesar $8 \mathrm{~mm}$ sedangkan TCI memberikan rating 0 untuk curah hujan $240 \mathrm{~mm}(8 \mathrm{~mm} / \mathrm{hari})$. Aspek fisik pada metode TCI kurang begitu baik untuk daerah dengan kondisi curah hujan yang tinggi sehingga penerapan TCI di daerah yang memiliki suhu dan curah hujan tinggi kurang baik

Tabel 15 Nilai TCI dan HCI pada ilustrasi musim hujan dan kemarau Jatim Park 2

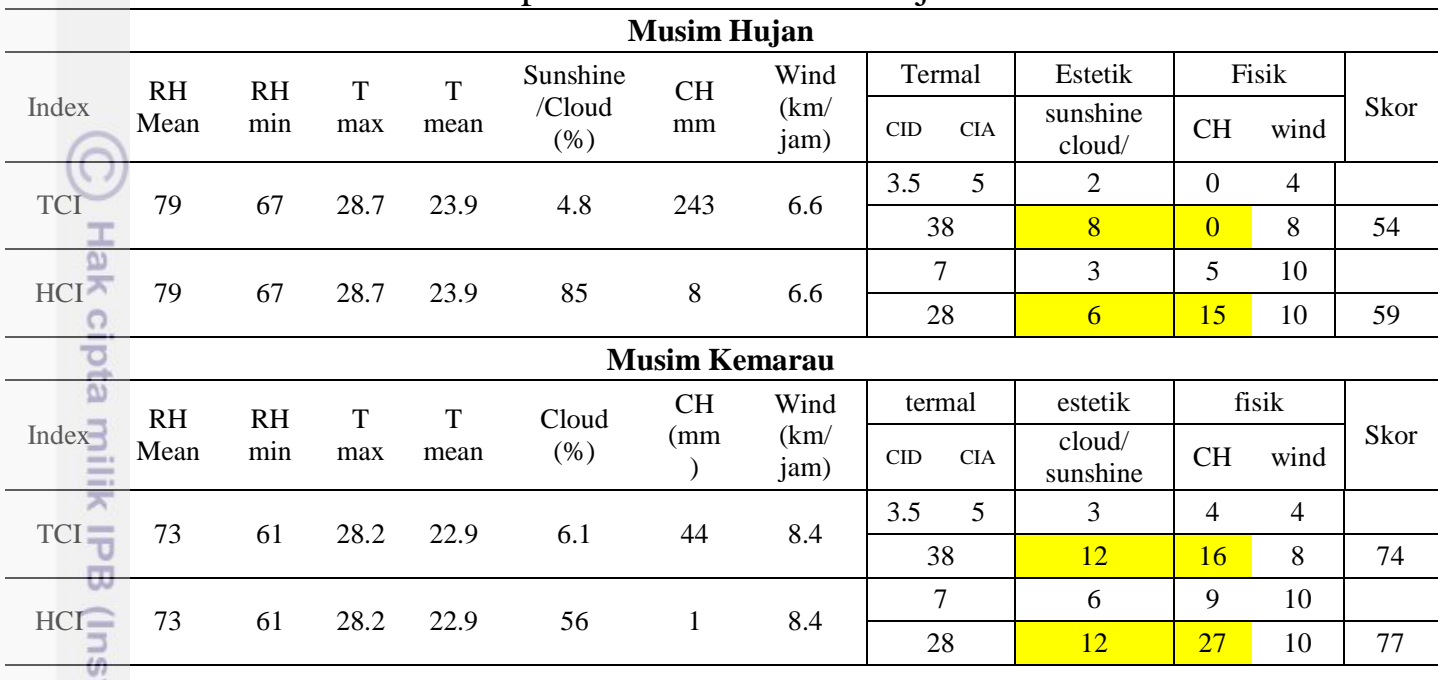

Berdasarkan tabel 15, selisih skor TCI dan HCI pada ilustrasi kedua musim relatif kecil. Pada musim hujan, kondisi kenyamanan dikategorikan ditoleransi sedangkan pada musim kemarau dikategorikan nyaman. Meski aspek fisik (curah hujan) pada TCI memberikan rating yang rendah di musim hujan, namun aspek termal TCI memberikan skor yang tinggi dikarenakan suhu udara di Jatim Park 2 berada pada kisaran $20-26^{\circ} \mathrm{C}$ yang relatif sejuk. Selain itu kehandalan Grafik CID dan CIA cukup baik untuk mengidentifikasi aspek termal TCI pada wilayah yang memiliki suhu udara pada kisaran $20-27^{\circ} \mathrm{C}$.

Indeks HCI berdasarkan ulasan diatas cenderung memberikan skor yang lebih baik dibandingkan indeks TCI. Pemerataan bobot HCI pada 3 aspek utama (termal, estetika dan fisik) menjadikan kondisi iklim yang sangat buruk dan sangat baik sulit tercapai jika hanya salah satu aspek saja yang bernilai buruk atau baik. Kondisi iklim yang baik dan cocok untuk kegiatan pariwisata akan tercapai jika ke tiga aspek utama berada pada kondisi baik. Pada musim kemarau indeks HCI dan TCI memberikan nilai tinggi untuk kondisi iklim musim kemarau. Selisih antara skor HCI dan TCI kecil karena nilai dari aspek estetik dan fisik TCI cukup tinggi. Hal ini menunjukan bahwa metode TCI cukup baik digunakan pada wilayah yang memiliki curah hujan yang rendah.

Penerapan HCI dan TCI berdasarkan sensitivitas dari kedua metode memiliki karakteristik yang berbeda. Metode HCI cukup baik diterapkan di daerah yang memiliki suhu udara dan curah hujan yang tinggi sehingga HCI dapat diterapkan di Taman Wisata Karangkates dan Jatim Park 2. Sedangkan metode TCI memiliki kelemahan jika diterapkan di daerah yang memiliki curah hujan yang tinggi tetapi cukup baik diterapkan di daerah yang memiliki suhu udara kisaran $20-27^{\circ} \mathrm{C}$ sehingga metode TCI dapat diterapkan di Jatim Park 2 dan daerah lainnya yang 

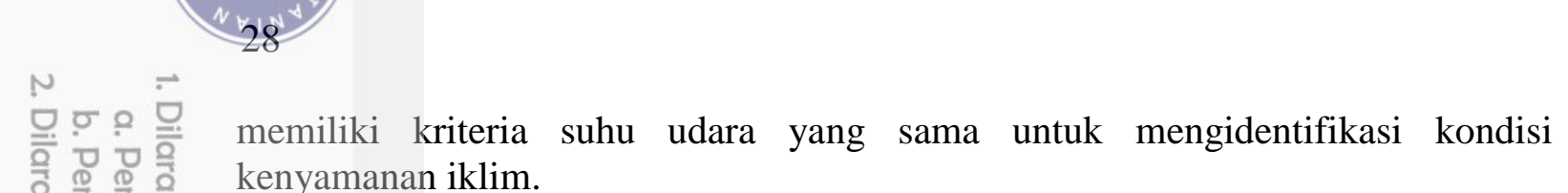
을 흘 을

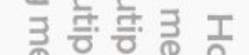

을 을 을 잉

둔

3응을 훙 훙

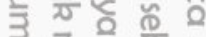

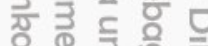

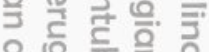

응 을 중을 읃

寻 일 융

万人

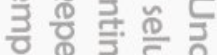

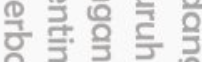

을 중

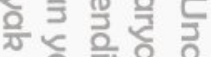

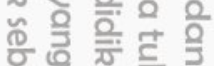

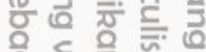

능. 응.

일

울 可突

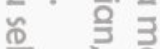

달

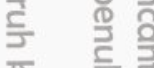

윽 产 喜

질 을

들 궁

코 을

을 3

을 흘 올

$\frac{0}{3} \sqrt{1} \frac{1}{2}$

蛋 离

둥

응 을

응 응 흉

ᄃ 음

용

흥 흥

ㅊ. 를

吕 을

龒 


\section{SIMPULAN DAN SARAN}

\section{Simpulan}

Hasil Penelitian di Taman Wisata Karangkates dan Jatim Park 2 tahun 2000 hingga 2009, kondisi iklim yang nyaman terjadi pada musim kemarau. Berdasarkan metode THI, Jatim Park 2 sepanjang tahun 2000-2009 dikategorikan nyaman sedangkan Taman Wisata karangkates terdapat 19 bulan dikategorikan tidak nyaman karena terlalu panas. Sementara itu, hasil dari metode TCI dan HCI, Jatim Park 2 memiliki puncak kenyamanan iklim pada bulan Juni hingga September sedangkan Taman Wisata Karangkates pada bulan Juli dan Agustus. Berdasarkan ketiga metode, kondisi iklim yang nyaman di kedua objek wisata terjadi pada bulan yang memiliki curah hujan rendah.

‥ Hasil analisis sensitivitas metode pada ilustrasi musim hujan dan kemarau meñunjukan bahwa metode HCI cukup baik diterapkan di kedua objek wisata sehingga HCI dapat diterapkan di daerah yang memiliki suhu udara dan curah hujan yang relatif tinggi seperti di daerah tropis. Sedangkan metode TCI kurang baik diterapkan di Taman Wisata Karangkates yang memiliki suhu dan curah hujan yang tinggi namun TCI masih baik diterapkan di Jatim Park 2 yang memiliki suhu udara yang relatif sejuk $\left(20-26^{\circ} \mathrm{C}\right)$ dimana TCI relatif baik jika diterapkan di wilayah yang memiliki suhu udara $20-27^{\circ} \mathrm{C}$.. Kelemahan TCI terletak pada rating curah hujan yang kurang tepat dan menitikberatkan pada aspek termal..

\section{Saran}

Penelitian ini menggunakan dua metode yang dirancang di Eropa yaitu HCI dan TCI dimana teknik pembobotan dan rating masih berdasarkan data iklim di daerah eropa sehingga sensitivitas dari kedua metode belum sepenuhnya handal dan bermasalah jika diterapkan di daerah yang memiliki curah hujan tinggi. Oleh karena itu perlu dilakukan modifikasi teknik pembobotan dan rating yang didasarkan pada data iklim di daerah tropis. 


\section{DAFTAR PUSTAKA}

Arifin RR. 2011. Analisis dampak perubahan iklim lokal terhadap permintaan pariwisata kawasan Pantai Anyer, Banten (kasus Pantai Bandulu Anyer) [skripsi]. Bogor: Institut Pertanian Bogor.

Badan Pusat Statistik Kota Wisata Batu. 2013. Pubikasi BPS: Kota Batu Dalam Angka 2013. [terhubung berkala] http://batukota.bps.go.id/ (Diakses pada 25 Agustus 2015)

BMKG. 2015. Analisis Distribusi Curah Hujan Malang Bulanan Tahun 2015. [Terhubung berkala]

http://karangploso.jatim.bmkg.go.id/index.php/component/tags/tag/105analisis-distribusi-curah-hujan-malang-bulanan-tahun2015\#ixzz31KfM9fwD\&gsc.tab=0 (Diakses pada 7 Desember 2015)

De Freitas, C.R. 2003. Tourism climatology: Evaluating Environmental Information for Decision Making and Business Planning in the Recreation and Tourism Sector. Int. J. Biometeorologi. 48, 45-54.

Effendy S:Bey A, Zain AFM, Santosa I. 2006. Peranan Ruang Terbuka Hijau dalam Mengendalikan Suhu Udara dan Urban Heat Island Wilayah JABOTABEK. J Agromet Indonesia 20(1):23-33.

Emmanuel R. 2005 Thermal Comfort Implications of Urbanization in a Warmhumid City: The Colombo Metropolitan Region (CMR), Sri Lanka. J Building and Evironment 40: 1591- 1601.

HamiltonJM, Lau MA. 2005. The role of climate information in tourist destination choice decision-making. In: Proceedings of the 17th International Congress of Biometeorology (ICB 2005), Garmisch-Partenkirchen, Germany, 9-5 September 2005. Deutscher Wetterdienst, Offenbach am Main, pp 608-611

Harrison,-S., Winterbottom, S. and Sheppard, C. (1999). The Potential Effects of Climate Change on the Scottish Tourist Industry, Tourism Management 20: 203211.

Hein, L. 2007. The impact of climate change on tourism in Spain. Centre for International Climate and Environmental Research, Oslo. CICERO Working Paper 2007:2.

Hidayat IW. 2010. The Ecological Role of Trees and Their Interactions in forming the Microclimate Amenity of Environment. J Bumi Lestari 10(2):182-190

Kakon AN, Nobuo M, Kojima S, Yoko T. 2010. Assessment of Thermal Comfort in Respect to Building Height in a High- Density City in the Tropics. J Engineering and Applied Sciences 3(3):545-551.

Kurnia, R. Effendy, S, Tursilowati, L. 2010. Identifikasi kenyamanan termal bangunan (studi kasus: ruang kuliah kampus IPB Baranangsiang dan Darmaga Bogor). Jurnal Agromet 24 (I): Halaman 14-22.

Lakitan B. 2002. Dasar-dasar Klimatologi. Jakarta: Raja Grafindo Persada.

Lin, T.P. and Matzarakis, A. 2008. Tourism Climate and Thermal Comfort in Sun Moon Lake, "Taiwan International Journal of Biometeorology 52: 281-290.

Lippsmeier Georg. 1994. Bangunan Tropis. Jakarta (ID); Erlangga.

Matzarakis, A., de Freitas, C., Scott, D. 2004. Advances in Tourism climatology. Berichte des Meteorologischen Institutes der Universität, Freiburg 
Mieczkowski, Z. (1985). The tourism climate index: A method for evaluating world climates for tourism. - The Canadian Geographer 29: 220-233

Pitana dan Diarta, 2009. Pengantar Ilmu Pariwisata. Yogyakarta (ID); ANDI

Rahardjo, T. S. B. 2001. Strategi Promosi Taman Aquarium Air Tawar Mini Indonesia Indah [skripsi]. Bogor; Institut Pertanian Bogor, Fakultas Perikanan dan Ilmu Kelautan.

Sa'at, A., U.S. Wiradisastra, Sudarsono, dan H. Pawitan. 1999. Kajian usaha perbaikan faktor penghambat kesesuaian lahan. Hlm 1385-1403 pros. Kongres Nasional VII HITI. Bandung, 2-4 November 1999

Scott, D. \& Lemieux, C. (2010). Weather and Climate Information for Tourism. Procedia Environmental Sciences. 1, 146-183.

Scott, D., McBoyle, G. \& Schwartzentruber, M. (2004). Climate Change and the Distribution of Climatic Resources for Tourism in North America. Climate Research, 27(2), 105-117.

Talaia, M., Meles, B. \& Teixeira, L. (2013). Evaluation of the Thermal Comfort in Workplaces - a study in the Metalworking Industry. Occupational Safety and Hygiene. Editors Arezes et al. Taylor \& Francis Group, London, 473-477. 


\section{LAMPIRAN}

T Lampiran 1 Sub indeks TCI Taman Wisata Karangkates

\begin{tabular}{|c|c|c|c|c|c|c|}
\hline \multirow[b]{2}{*}{ Tanggal } & \multicolumn{6}{|c|}{ Sub Indeks TCI } \\
\hline & $\begin{array}{c}\text { Lama } \\
\text { Penyinaran }\end{array}$ & $\begin{array}{c}\text { kecepatan } \\
\text { angin }\end{array}$ & $\begin{array}{l}\text { Curah } \\
\text { hujan }\end{array}$ & CID & CIA & $\begin{array}{c}\text { Skor } \\
\text { TCI }\end{array}$ \\
\hline Jan-00 & 2.00 & 4.50 & 0.00 & 2.00 & 4.50 & 42 \\
\hline Feb-00 & 1.00 & 4.00 & 0.00 & 2.00 & 4.00 & 36 \\
\hline Mar-00 & 2.00 & 4.50 & 0.00 & 1.00 & 4.50 & 34 \\
\hline Apr-00 & 2.50 & 4.50 & 0.00 & 1.00 & 4.00 & 35 \\
\hline May-00 & 3.00 & 4.00 & 1.50 & 1.00 & 4.50 & 43 \\
\hline Jun-00T & 2.50 & 4.00 & 3.00 & 2.00 & 4.50 & 55 \\
\hline Jul-00天 & 3.50 & 3.50 & 5.00 & 1.50 & 4.50 & 62 \\
\hline Aug- 00 - & 3.00 & 3.50 & 5.00 & 2.00 & 5.00 & 65 \\
\hline Sep-00 & 3.50 & 3.50 & 5.00 & 1.00 & 4.00 & 57 \\
\hline Oct-003 & 2.00 & 4.00 & 0.00 & 2.00 & 4.50 & 41 \\
\hline Nov-00 & 1.50 & 4.00 & 0.00 & 2.00 & 4.50 & 39 \\
\hline Dec-00= & 3.00 & 4.00 & 0.00 & 2.00 & 4.00 & 44 \\
\hline Jan-01 & 2.00 & 4.50 & 0.00 & 1.50 & 3.50 & 36 \\
\hline Feb-01亏 & 2.00 & 4.00 & 0.00 & 1.50 & 4.00 & 36 \\
\hline Mar- $01 \stackrel{\text { a }}{=}$ & 2.50 & 4.50 & 0.00 & 1.00 & 3.50 & 34 \\
\hline Apr-01를 & 3.00 & 4.00 & 0.00 & 1.50 & 2.50 & 37 \\
\hline May-01ग & 3.50 & 4.00 & 4.00 & 1.50 & 3.00 & 56 \\
\hline Jun-017- & 3.00 & 4.00 & 0.00 & 2.00 & 4.00 & 44 \\
\hline Jul-01క & 3.00 & 4.00 & 3.50 & 3.00 & 4.50 & 67 \\
\hline Aug-01戸 & 3.00 & 3.50 & 4.00 & 2.50 & 5.00 & 65 \\
\hline Sep-010 & 3.50 & 3.50 & 3.50 & 2.50 & 4.00 & 63 \\
\hline Oct-010 & 3.00 & 4.00 & 0.00 & 1.50 & 3.00 & 38 \\
\hline Nov-01글 & 3.00 & 4.00 & 0.00 & 1.50 & 3.00 & 38 \\
\hline Dec-01 & 1.50 & 4.50 & 0.00 & 1.50 & 5.00 & 37 \\
\hline Jan-02 & 2.00 & 4.50 & 0.00 & 1.00 & 3.50 & 32 \\
\hline Feb-02 & 0.50 & 4.00 & 0.00 & 1.00 & 3.50 & 25 \\
\hline Mar-02 & 1.00 & 4.50 & 0.00 & 0.00 & 4.00 & 21 \\
\hline Apr-02 & 2.50 & 4.00 & 0.00 & 0.00 & 5.00 & 28 \\
\hline May-02 & 2.50 & 4.00 & 0.00 & 0.50 & 3.00 & 28 \\
\hline Jun-02 & 1.00 & 3.50 & 0.00 & 0.50 & 3.00 & 21 \\
\hline Jul-02 & 3.00 & 3.50 & 4.00 & 0.50 & 3.00 & 45 \\
\hline Aug-02 & 1.50 & 3.50 & 2.50 & 2.00 & 4.00 & 47 \\
\hline Sep-02 & 3.00 & 3.50 & 4.50 & 1.00 & 4.00 & 53 \\
\hline Oct-020 & 3.50 & 4.00 & 4.50 & 0.00 & 4.00 & 48 \\
\hline Nov-02 & 3.00 & 4.00 & 1.50 & 0.50 & 2.50 & 35 \\
\hline Dec-02 & 0.00 & 4.50 & 0.00 & 2.00 & 3.50 & 32 \\
\hline Jan-03 & 2.00 & 4.00 & 0.00 & 0.50 & 4.00 & 28 \\
\hline Feb-03 & 1.50 & 4.00 & 0.00 & 1.00 & 3.50 & 29 \\
\hline Mar-03 & 3.00 & 4.50 & 0.00 & 0.50 & 3.50 & 32 \\
\hline Apr-03 & 3.50 & 4.00 & 2.00 & 0.50 & 4.00 & 42 \\
\hline
\end{tabular}




\begin{tabular}{|c|c|c|c|c|c|c|}
\hline May-03 & 3.50 & 4.00 & 3.50 & 1.00 & 4.00 & 52 \\
\hline Jun-03 & 3.50 & 4.00 & 5.00 & 1.00 & 4.50 & 59 \\
\hline Jul-03 & 3.50 & 3.50 & 5.00 & 2.00 & 4.00 & 65 \\
\hline Aug-03 & 3.50 & 3.50 & 5.00 & 1.00 & 5.00 & 59 \\
\hline Sep-03 & 3.50 & 3.50 & 4.50 & 1.00 & 4.00 & 55 \\
\hline Oct-03 & 3.00 & 3.50 & 2.50 & 1.50 & 4.50 & 50 \\
\hline Nov-03 & 2.00 & 4.00 & 0.00 & 2.00 & 3.50 & 39 \\
\hline Dec-03 & 1.50 & 4.00 & 0.00 & 4.50 & 5.00 & 60 \\
\hline Jan-04 & 2.50 & 4.50 & 0.00 & 2.50 & 3.50 & 46 \\
\hline Feb-04 & 2.00 & 4.00 & 0.00 & 2.00 & 4.00 & 40 \\
\hline Mar-04 & 2.00 & 4.50 & 0.00 & 2.50 & 4.00 & 45 \\
\hline Apr-04 & 3.50 & 4.00 & 1.00 & 0.50 & 4.00 & 38 \\
\hline May-04 & 3.00 & 4.00 & 3.00 & 1.50 & 4.00 & 52 \\
\hline Jün-04 & 3.50 & 4.00 & 3.50 & 1.50 & 5.00 & 58 \\
\hline Jul-04 & 3.50 & 4.00 & 4.50 & 2.00 & 5.00 & 66 \\
\hline Aưg-04 & 3.50 & 3.50 & 5.00 & 1.50 & 5.00 & 63 \\
\hline Sep-04 & 3.50 & 3.50 & 4.50 & 1.50 & 4.00 & 59 \\
\hline Oct-04 & 3.50 & 4.00 & 5.00 & 0.50 & 4.00 & 54 \\
\hline Nov-04 & 2.00 & 4.00 & 0.00 & 0.50 & 4.00 & 28 \\
\hline Dec-04 & 1.50 & 4.50 & 0.00 & 2.50 & 4.00 & 43 \\
\hline Jān-05 & 2.00 & 4.50 & 0.00 & 1.50 & 4.00 & 37 \\
\hline Feb-05 & 2.00 & 4.50 & 0.00 & 1.00 & 3.00 & 31 \\
\hline Mar-05 & 2.50 & 4.50 & 0.00 & 1.00 & 4.00 & 35 \\
\hline Apr-05 & 3.00 & 4.00 & 0.00 & 0.50 & 3.50 & 31 \\
\hline May-05 & 3.50 & 4.00 & 5.00 & 0.50 & 4.00 & 54 \\
\hline Jün-05 & 3.00 & 4.00 & 1.50 & 1.50 & 4.00 & 46 \\
\hline ful-05 & 3.00 & 4.00 & 0.50 & 3.00 & 5.00 & 56 \\
\hline Aug-05 & 3.00 & 3.50 & 4.00 & 2.00 & 4.50 & 60 \\
\hline Sep-05 & 3.50 & 3.50 & 2.50 & 2.00 & 3.50 & 54 \\
\hline Oet-05 & 3.00 & 4.00 & 0.00 & 1.50 & 4.00 & 40 \\
\hline Nov-05 & 3.00 & 4.00 & 0.00 & 1.50 & 3.50 & 39 \\
\hline Dec-05 & 2.00 & 4.50 & 0.00 & 2.50 & 4.50 & 46 \\
\hline Jan-06 & 2.50 & 4.00 & 0.00 & 1.50 & 4.00 & 38 \\
\hline Feb-06 & 1.50 & 4.50 & 0.00 & 2.00 & 4.00 & 39 \\
\hline Mar-06 & 2.00 & 4.50 & 0.00 & 1.00 & 3.50 & 32 \\
\hline Apr-06 & 2.50 & 4.50 & 0.00 & 1.00 & 3.00 & 33 \\
\hline May-06 & 2.50 & 4.00 & 1.00 & 1.00 & 4.00 & 38 \\
\hline Jun-06 & 2.50 & 3.50 & 5.00 & 1.50 & 5.00 & 59 \\
\hline Jul-06 & 3.00 & 3.50 & 5.00 & 2.50 & 5.00 & 69 \\
\hline Aug-06 & 3.00 & 3.50 & 5.00 & 2.50 & 5.00 & 69 \\
\hline Sep-06 & 3.50 & 3.50 & 5.00 & 2.00 & 4.50 & 66 \\
\hline Oct-06 & 3.50 & 3.50 & 4.50 & 1.00 & 4.50 & 56 \\
\hline Nov-06 & 3.00 & 4.00 & 0.00 & 0.00 & 3.50 & 27 \\
\hline Dec-06 & 2.00 & 4.50 & 0.00 & 0.00 & 3.50 & 24 \\
\hline Jan-07 & 3.00 & 4.00 & 2.00 & 1.50 & 4.00 & 48 \\
\hline Feb-07 & 2.00 & 4.50 & 0.00 & 1.50 & 4.50 & 38 \\
\hline
\end{tabular}




\begin{tabular}{|c|c|c|c|c|c|c|c|}
\hline 뭄 & Mar-07 & 1.50 & 4.00 & 0.00 & 1.50 & 3.50 & 33 \\
\hline . & Apr-07 & 2.00 & 4.50 & 0.00 & 1.00 & 4.50 & 34 \\
\hline & Мay-07 & 3.00 & 4.00 & 2.50 & 1.00 & 3.50 & 45 \\
\hline$\frac{T}{Q}$ & Jun-07 & 2.50 & 4.00 & 0.00 & 2.00 & 4.50 & 43 \\
\hline & Jul-07 & 3.00 & 3.50 & 4.50 & 2.50 & 5.00 & 67 \\
\hline 4 & Aug-07 & 3.00 & 3.50 & 5.00 & 1.50 & 5.00 & 61 \\
\hline ¿ & Sep-07 & 3.50 & 3.50 & 5.00 & 1.50 & 5.00 & 63 \\
\hline & Oct-07 & 3.00 & 4.00 & 0.00 & 0.50 & 4.00 & 32 \\
\hline$\frac{0}{2}$ & Nov-07 & 2.50 & 4.00 & 0.50 & 0.00 & 4.50 & 29 \\
\hline & Dec-07 & 1.50 & 4.50 & 0.00 & 0.00 & 4.50 & 24 \\
\hline & Jan-08 & 2.50 & 4.00 & 0.00 & 2.00 & 4.00 & 42 \\
\hline & Feb-08 & 1.50 & 4.00 & 0.00 & 3.00 & 4.00 & 46 \\
\hline & Mar-08 & 1.00 & 4.50 & 0.00 & 1.50 & 3.50 & 32 \\
\hline$\Phi$ & $\mathrm{Apr}-08^{\pi}$ & 3.00 & 4.00 & 1.50 & 1.00 & 3.50 & 41 \\
\hline & May-08 & 3.00 & 3.50 & 1.50 & 2.50 & 4.00 & 53 \\
\hline & Jun-08 & 3.00 & 4.00 & 1.50 & 2.00 & 5.00 & 52 \\
\hline & Jul-08 & 3.50 & 3.50 & 5.00 & 3.00 & 5.00 & 75 \\
\hline & Aug-08 & 3.00 & 3.50 & 5.00 & 2.50 & 4.50 & 68 \\
\hline & Sep-08 & 3.00 & 3.50 & 5.00 & 1.50 & 4.00 & 59 \\
\hline 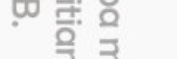 & Oct-08 & 2.50 & 4.00 & 1.00 & 1.00 & 3.00 & 36 \\
\hline & Nov- $08 \bar{\Xi}$ & 1.00 & 4.00 & 0.00 & 1.00 & 3.50 & 27 \\
\hline ב & Dec-08 & 1.50 & 4.00 & 0.00 & 1.00 & 4.00 & 30 \\
\hline & Jan-09= & 2.00 & 4.00 & 0.00 & 1.00 & 4.00 & 32 \\
\hline & Feb-09 & 1.50 & 4.00 & 0.00 & 2.00 & 4.00 & 38 \\
\hline & Mar-09- & 3.00 & 4.50 & 0.00 & 1.50 & 3.50 & 40 \\
\hline$\stackrel{ㅇ}{2}$ & Apr-09ב. & 3.00 & 4.00 & 1.50 & 1.50 & 3.50 & 45 \\
\hline & May-09ङ & 2.50 & 4.00 & 0.00 & 2.00 & 5.00 & 44 \\
\hline & Jun-090 & 3.50 & 4.00 & 4.00 & 2.00 & 4.50 & 63 \\
\hline 0 & Jul-09응 & 3.50 & 3.50 & 5.00 & 3.00 & 5.00 & 75 \\
\hline$z$ & Aug-09 & 3.50 & 3.50 & 5.00 & 3.00 & 5.00 & 75 \\
\hline & Sep-09 & 3.00 & 3.50 & 4.00 & 2.00 & 4.50 & 60 \\
\hline & Oct-09 & 3.50 & 3.50 & 4.50 & 2.00 & 4.00 & 63 \\
\hline & Nov-09 & 2.50 & 4.00 & 0.00 & 1.50 & 4.50 & 39 \\
\hline & Dec-09 & 3.00 & 4.50 & 2.50 & 1.50 & 4.00 & 51 \\
\hline
\end{tabular}


Lampiran 2 Sub indeks TCI Taman Wisata Jatim Park 2

\begin{tabular}{|c|c|c|c|c|c|c|}
\hline \multirow[b]{2}{*}{ Tanggal } & \multicolumn{6}{|c|}{ Sub Indeks TCI } \\
\hline & $\begin{array}{c}\text { Lama } \\
\text { Penyinaran }\end{array}$ & $\begin{array}{c}\text { kecepatan } \\
\text { angin }\end{array}$ & $\begin{array}{l}\text { Curah } \\
\text { hujan }\end{array}$ & CID & CIA & $\begin{array}{l}\text { Skor } \\
\text { TCI }\end{array}$ \\
\hline Jan-00 & 1.00 & 4.00 & 0.00 & 4.00 & 5.00 & 54 \\
\hline Feb-00 & 1.00 & 4.00 & 0.00 & 4.00 & 5.00 & 54 \\
\hline Mar-00 & 1.50 & 4.00 & 0.00 & 3.50 & 5.00 & 52 \\
\hline Apr-00 & 1.50 & 4.50 & 1.50 & 3.50 & 5.00 & 59 \\
\hline May-00 & 2.00 & 4.50 & 0.50 & 3.50 & 5.00 & 57 \\
\hline Jun-00 & 2.50 & 4.00 & 4.00 & 4.00 & 5.00 & 76 \\
\hline Jul-00 & 2.50 & 3.50 & 5.00 & 3.50 & 5.00 & 75 \\
\hline Aug-00 & 3.00 & 3.50 & 5.00 & 4.50 & 5.00 & 85 \\
\hline Sep-00 & 3.50 & 3.50 & 2.00 & 3.00 & 5.00 & 63 \\
\hline Oct-00 & 2.50 & 4.00 & 0.00 & 4.00 & 5.00 & 60 \\
\hline Nov-00 & 1.50 & 4.50 & 0.00 & 3.00 & 5.00 & 49 \\
\hline Dec-00 & 2.00 & 4.00 & 2.00 & 3.50 & 5.00 & 62 \\
\hline Jan-01 & 1.50 & 4.50 & 0.00 & 3.50 & 5.00 & 53 \\
\hline Fèb-01 & 1.50 & 3.50 & 0.00 & 4.00 & 5.00 & 55 \\
\hline Mar-01 & 1.50 & 4.50 & 0.00 & 3.50 & 5.00 & 53 \\
\hline Apr-01 & 2.50 & 4.50 & 4.00 & 3.50 & 5.00 & 73 \\
\hline May-01 & 3.00 & 4.00 & 1.50 & 3.50 & 5.00 & 64 \\
\hline Jun-01 & 3.00 & 4.00 & 1.00 & 3.50 & 5.00 & 62 \\
\hline Jul-01 & 3.00 & 4.00 & 4.00 & 5.00 & 5.00 & 86 \\
\hline Aug-01 & 3.00 & 3.50 & 5.00 & 4.50 & 5.00 & 85 \\
\hline Sep-01 & 3.00 & 3.50 & 4.50 & 3.50 & 5.00 & 75 \\
\hline Oct-01 & 2.00 & 4.00 & 0.00 & 3.50 & 5.00 & 54 \\
\hline Nov-01 & 2.00 & 4.00 & 0.50 & 4.00 & 5.00 & 60 \\
\hline Dec-01 & 1.00 & 4.00 & 0.00 & 4.00 & 5.00 & 54 \\
\hline Tan-02 & 2.00 & 4.50 & 0.00 & 3.00 & 5.00 & 51 \\
\hline Feb-02 & 1.50 & 3.50 & 0.00 & 3.50 & 5.00 & 51 \\
\hline Mar-02 & 2.50 & 4.50 & 0.50 & 3.00 & 5.00 & 55 \\
\hline Apr-02 & 2.50 & 4.50 & 0.00 & 3.50 & 5.00 & 57 \\
\hline May-02 & 3.00 & 4.00 & 3.50 & 3.50 & 5.00 & 72 \\
\hline Jun-02 & 3.00 & 3.50 & 5.00 & 4.00 & 5.00 & 81 \\
\hline Jul-02 & 3.00 & 3.50 & 5.00 & 4.00 & 5.00 & 81 \\
\hline Aug-02 & 3.50 & 3.50 & 5.00 & 4.00 & 5.00 & 83 \\
\hline Sep-02 & 3.00 & 3.50 & 5.00 & 3.50 & 5.00 & 77 \\
\hline Oct-02 & 3.50 & 4.00 & 5.00 & 2.50 & 5.00 & 72 \\
\hline Nov-02 & 2.50 & 4.00 & 2.00 & 2.50 & 5.00 & 56 \\
\hline Dec-02 & 2.00 & 4.50 & 0.00 & 2.50 & 5.00 & 47 \\
\hline Jan-03 & 2.00 & 4.00 & 0.00 & 3.00 & 5.00 & 50 \\
\hline Feb-03 & 1.50 & 4.00 & 0.00 & 3.50 & 5.00 & 52 \\
\hline Mar-03 & 2.00 & 4.00 & 0.00 & 3.00 & 5.00 & 50 \\
\hline Apr-03 & 3.00 & 4.00 & 4.00 & 3.00 & 5.00 & 70 \\
\hline May-03 & 2.50 & 4.00 & 2.00 & 3.50 & 5.00 & 64 \\
\hline Jun-03 & 3.00 & 4.00 & 4.50 & 4.00 & 5.00 & 80 \\
\hline Jul-03 & 3.50 & 3.50 & 5.00 & 4.00 & 5.00 & 83 \\
\hline
\end{tabular}




\begin{tabular}{|c|c|c|c|c|c|c|}
\hline Aug-03 & 3.00 & 3.50 & 5.00 & 3.50 & 5.00 & 77 \\
\hline Sep-03 & 2.50 & 3.50 & 5.00 & 3.00 & 5.00 & 71 \\
\hline Oct-03 & 2.50 & 4.00 & 3.50 & 3.00 & 5.00 & 66 \\
\hline Nov-03 & 2.00 & 4.00 & 0.00 & 2.50 & 5.00 & 46 \\
\hline Dec-03 & 0.00 & 4.00 & 0.00 & 3.50 & 5.00 & 46 \\
\hline Jan-04 & 1.50 & 4.00 & 0.00 & 3.00 & 5.00 & 48 \\
\hline Feb-04 & 1.50 & 4.00 & 0.00 & 3.50 & 5.00 & 52 \\
\hline Mar-04 & 1.50 & 4.00 & 0.00 & 3.00 & 5.00 & 48 \\
\hline Apr-04 & 3.00 & 4.00 & 4.00 & 2.50 & 5.00 & 66 \\
\hline May-04 & 2.50 & 4.00 & 2.00 & 3.50 & 5.00 & 64 \\
\hline Jun-04 & 3.00 & 4.00 & 5.00 & 4.00 & 5.00 & 82 \\
\hline Jul-04 & 3.00 & 3.50 & 5.00 & 4.00 & 5.00 & 81 \\
\hline Aug-04 & 3.00 & 3.50 & 5.00 & 4.00 & 5.00 & 81 \\
\hline Sep-04 & 3.00 & 3.50 & 5.00 & 3.50 & 5.00 & 77 \\
\hline Oct-04 & 3.00 & 4.00 & 4.50 & 2.50 & 5.00 & 68 \\
\hline Nov-04 & 2.50 & 4.50 & 0.00 & 3.00 & 5.00 & 53 \\
\hline Dec-04 & 1.00 & 4.00 & 0.00 & 3.00 & 5.00 & 46 \\
\hline Jan-05 & 2.00 & 4.00 & 0.00 & 3.00 & 5.00 & 50 \\
\hline Feb-05 & 2.00 & 4.50 & 0.00 & 2.50 & 5.00 & 47 \\
\hline Mar-05 & 2.00 & 4.50 & 0.00 & 2.50 & 5.00 & 47 \\
\hline Apr-05 & 2.50 & 4.00 & 0.00 & 3.00 & 5.00 & 52 \\
\hline May-05 & 3.00 & 3.50 & 5.00 & 3.00 & 5.00 & 73 \\
\hline Jun-05 & 2.50 & 4.00 & 5.00 & 3.00 & 5.00 & 72 \\
\hline Jul-05 & 2.50 & 4.00 & 3.00 & 3.50 & 5.00 & 68 \\
\hline Aug-05 & 2.50 & 3.50 & 5.00 & 4.00 & 5.00 & 79 \\
\hline Sep-05. & 3.00 & 4.00 & 5.00 & 3.00 & 5.00 & 74 \\
\hline Oct-05 & 2.50 & 4.00 & 2.50 & 3.00 & 5.00 & 62 \\
\hline Nov-05 & 2.50 & 4.00 & 0.00 & 3.50 & 5.00 & 56 \\
\hline Dec-05 & 1.00 & 4.50 & 0.00 & 3.00 & 5.00 & 47 \\
\hline Jan-06 & 1.50 & 4.00 & 0.00 & 4.00 & 5.00 & 56 \\
\hline Feb-06 & 1.50 & 4.00 & 0.00 & 3.00 & 5.00 & 48 \\
\hline Mar-06 & 1.00 & 4.50 & 0.00 & 3.00 & 5.00 & 47 \\
\hline Apr-06 & 1.50 & 4.50 & 0.00 & 3.00 & 5.00 & 49 \\
\hline May-06 & 1.00 & 4.00 & 0.00 & 3.50 & 5.00 & 50 \\
\hline Jun-06 & 2.50 & 4.00 & 4.50 & 4.50 & 5.00 & 82 \\
\hline Jul-06 & 3.00 & 3.50 & 5.00 & 4.00 & 5.00 & 81 \\
\hline Aug-06 & 3.00 & 3.50 & 5.00 & 4.00 & 5.00 & 81 \\
\hline Sep-06 & 3.50 & 3.50 & 5.00 & 4.00 & 5.00 & 83 \\
\hline Oct-06 & 3.00 & 3.50 & 4.50 & 3.00 & 5.00 & 71 \\
\hline Nov-06 & 3.00 & 4.00 & 4.50 & 2.00 & 5.00 & 64 \\
\hline Dec-06 & 2.00 & 4.50 & 0.00 & 3.00 & 5.00 & 51 \\
\hline Jan-07 & 2.50 & 4.00 & 1.50 & 3.50 & 5.00 & 62 \\
\hline Feb-07 & 2.00 & 4.50 & 0.00 & 3.00 & 5.00 & 51 \\
\hline Mar-07 & 1.00 & 4.00 & 0.00 & 4.00 & 5.00 & 54 \\
\hline Apr-07 & 2.50 & 4.50 & 0.00 & 3.00 & 5.00 & 53 \\
\hline May-07 & 2.50 & 4.00 & 5.00 & 3.00 & 5.00 & 72 \\
\hline
\end{tabular}




\begin{tabular}{rrrrrrr} 
Jun-07 & 2.50 & 4.00 & 4.50 & 4.00 & 5.00 & 78 \\
\hline Jul-07 & 3.00 & 3.50 & 5.00 & 4.00 & 5.00 & 81 \\
\hline Aug-07 & 3.00 & 3.50 & 5.00 & 4.50 & 5.00 & 85 \\
\hline Sep-07 & 3.50 & 3.50 & 5.00 & 4.00 & 5.00 & 83 \\
\hline Oct-07 & 3.00 & 4.00 & 3.50 & 3.00 & 5.00 & 68 \\
\hline Nov-07 & 3.00 & 4.00 & 0.00 & 3.00 & 5.00 & 54 \\
\hline Dec-07 & 1.50 & 4.00 & 0.00 & 3.00 & 5.00 & 48 \\
\hline Jan-08 & 2.50 & 4.00 & 0.00 & 3.00 & 5.00 & 52 \\
\hline Feb-08 & 1.00 & 3.50 & 0.00 & 4.00 & 5.00 & 53 \\
\hline Mar-08 & 1.50 & 4.50 & 0.00 & 3.00 & 5.00 & 49 \\
\hline Apr-08 & 3.00 & 4.00 & 3.00 & 3.00 & 5.00 & 66 \\
\hline May-08 & 3.00 & 3.50 & 3.00 & 4.00 & 5.00 & 73 \\
\hline Jun-08 & 3.00 & 3.50 & 5.00 & 4.00 & 5.00 & 81 \\
\hline Jul-08 & 3.50 & 3.50 & 5.00 & 4.00 & 5.00 & 83 \\
\hline Aug-08 & 3.00 & 3.50 & 3.50 & 3.50 & 5.00 & 71 \\
\hline Sep-08 & 3.00 & 3.50 & 5.00 & 4.00 & 5.00 & 81 \\
\hline Oct-08 & 3.00 & 4.00 & 2.00 & 2.50 & 5.00 & 58 \\
\hline Nov-08 & 2.00 & 4.50 & 0.00 & 3.00 & 5.00 & 51 \\
\hline Dec-08 & 1.50 & 4.00 & 0.00 & 3.50 & 5.00 & 52 \\
\hline Jan-09 & 1.00 & 4.00 & 0.00 & 3.00 & 5.00 & 46 \\
\hline Feb-09 & 1.50 & 4.00 & 0.00 & 3.50 & 5.00 & 52 \\
\hline Mar-09 & 2.00 & 4.50 & 2.50 & 3.00 & 5.00 & 61 \\
\hline Apr-09 & 3.00 & 4.50 & 3.00 & 3.00 & 5.00 & 67 \\
\hline May-09 & 2.50 & 4.00 & 2.00 & 3.50 & 5.00 & 64 \\
\hline Jun-09 & 3.50 & 4.00 & 5.00 & 3.50 & 5.00 & 80 \\
\hline Jul-09 & 3.50 & 4.00 & 5.00 & 4.00 & 5.00 & 84 \\
\hline Aug-09 & 3.00 & 3.50 & 5.00 & 4.00 & 5.00 & 81 \\
\hline Sep-09 & 3.00 & 3.50 & 5.00 & 3.50 & 5.00 & 77 \\
\hline Oct-09 & 3.00 & 4.00 & 4.00 & 3.00 & 5.00 & 70 \\
\hline Nov-09 & 2.50 & 4.00 & 0.00 & 3.00 & 5.00 & 52 \\
\hline Dec-09 & 2.50 & 4.50 & 0.00 & 3.00 & 5.00 & 53 \\
\hline & & & & & \\
\hline
\end{tabular}




\section{RIWAYAT HIDUP}

I Penulis dilahirkan di Ciamis, tanggal 21 Juli 1993 sebagai anak pertama dari tiga bersaudara, anak pasangan dari Bapak Asep Kurnia dan Ika Aguseritani. Pada f tahun 2011, penulis menyelesaikan kegiatan belajar di SMA Negeri 1 Pangandaran. 2 Pada tahun yang sama, penulis diterima sebagai mahasiswa IPB Angkatan 48 melalui jalus SNMPTN Undangan dan terdaftar menjadi mahasiswa Program Studi Meteorologi Terapan, Departemen Geofisika dan Meteorologi, Fakultas Matematika dan Ilmu Pengetahuan Alam, Institut Pertanian Bogor. Selama masa studi di IPB, Penulis pernah aktif dalam Himpunan Profesi HIMAGRETO (Himpunan Mahasiswa Agrometeorologi) tahun 2012-2013 sebagai staff di Divisi Kominfo. Pada periode tahun 2013-2014, penulis berpartisipasi dalam kegiatan Meteorologi Interaktif (METRIK) Pesta Sains IPB tingkat nasional sebagai staf Leader Officer. Penulis juga aktif di kegiatan lainnya seperti mengikuti cabang futsal dan sepakbola di Olimpiade Mahasiswa IPB (OMI) dan SPIRIT FMIPA IPB pada tahun 2012-2015. Penulis sangat hobi di bidang olahraga dan sangat menyukai photografiedan juga musik. 